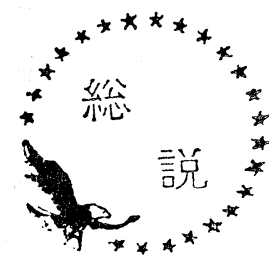

I 燃焼のガス力学

II 火炎構造

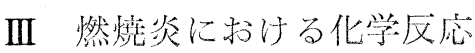

\section{燃焼の基礎的研究の動向}

\section{I 燃焼のガスカ学}

燃焼における流れの問題が特に注目されるようにな つてきたのは, 第二次大戦後, ジェットエンジンや口 ケットモータの上うな新しい推准機関が非常ないきお いで発達し, 高負荷燃焼が問題になり, 速い流れの中 に打ける燃焼が重要になつて以来のことである。この 高負荷燃燒に関連して, 乱流火炎, 高速気流中の火炎 安定化や振動燃焼などの問題がとりあげられ, まずこ れらの問題に関する実験的研究がす寸められた。1953 年 van Kármán が燃焼のよらな化学反态をともなつ た压縮性流体の力学を Aerothermochemistry (反応性 ガス力学）と命名し，その基礎方程式を確立したこと によつて燃燒のガス力学の基礎が固められ，流れをと もなつた燃焼の理論的解析がはじめて系統的に行なわ れるようになつた1。

しかし燃焼をともなつた流れの現象は複雑で解析が むずかしく, 初期の理諭的解析は主として, (1) 簡単 な一次元火炎や detonation wave の構造やその安定 性，(2) 不連続面として取扱つた火炎面が流れの場に およぼす影響などを調べる問題のいずれかに限られて いた。しかし高速気流中に肪ける火炎の着火や安定化 などのように反応性ガス力学に敌ける工学的に重要な 問題は，境界層近似によつて取り报うことができると いらことがわかり，気流中の燃燒の諸問題が1954年以 来, 反応性ガス力学の境界層近似を用いて集中的に解 析され, その結果複雑な現象が統一的に解明されるよ らになつた ${ }^{2) 3 \% 。 ~}$

前述の上らに気流中の燃焼の諸問題は, まず実験的 研究がす寸められ，かなりの成果があげられたが，す ぐその後を追らようにこれらの問題の理諭的解析が行 なわれた。実際，(1) 二つの自由気流の間の混合領域

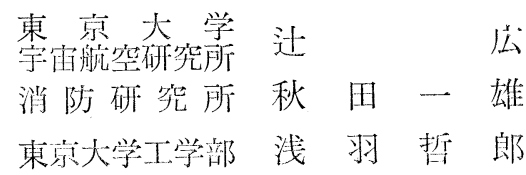

に打ける燃燒，(2) 平板後流の混合領域に和ける燃 焼, (3) 加熱平板に上る可燃性気流の着火および火炎 安定化，(4) 高温ジェットによる可燃性気流の着火, （5）可燃性ガスを吹き出した場合の境界層内の然燒, (6) 固体推進剤の浸蝕燃焼などについての研究が行な われたが，1962年以降これらの問題についての研究は 目立つて少なくなつてきた。このことは，これらの諸 問題が完全に解明され，またその重要性が失なわれた ことを意味するのではなく, 問題の非常に難しい部分 は依然として未解決で, 乱流火炎や振動燃焼などとと もに, 地味なしかも着実な研究がその後もひきつゔき 行なわれている。

しかし最近, 以上述べたような諸問題に代つて, 気 流中の燃焼についての二つの新しい問題が注目を浴び るようになつてきた。その一つは対向流拡散火炎であ り, 他の一つは超音速気流中の燃焼（いわゆる超音速 燃燒) である。よつてここではこの二つの新しい問題 をとりあげて説明することにする。

\section{1. 対向流拡散火炎}

空気中で然料噴流の燃焼を行なう場合, 燃料噴出速 度をあげてゆくと，拡散火炎が吹き消えることは古く から知られている。また空気流中に吊された液体然料 の球を完全にとりかこんでいる包絡形の拡散火炎(envelope flame) が, ある限界の空気流速に扝いて突然 後流形の火炎 (wake flame) に遷移するといら現象が 1953年はじめて Spalding に上つて観察された4)。こ のように拡散灭炎が消光る現象は火炎帯における反応 速度が有限であることに起因しているということを， Zeldovich や Spalding が理論的に示しているが5) 8), このことは，抎散火炎の吹き消え速度が反応速度の目 安を与えているといらことを示唆している。よつて非 常に反応性に富み, 予混合することが難かしい燃料・ 酸化剂の組合せに対しては，拡散火炎を用いてその吹 
き消え速度から反応速度を推定することが特に有用で 亦る。この点に注目して，まずPotter とその協力者た ちは，流出口を上下に対向させた二つの円管の一方か ら燃料を，他方から酸化剂を噴出させ，この二つの噴 流の衝突面附近に拡散火炎をつくり，この対向流拡散 火炎が吹き消えるときの流速を反応速度の目安として 採用するといら新しい実験方法を提案した(第1図) $)^{9)}$ 。

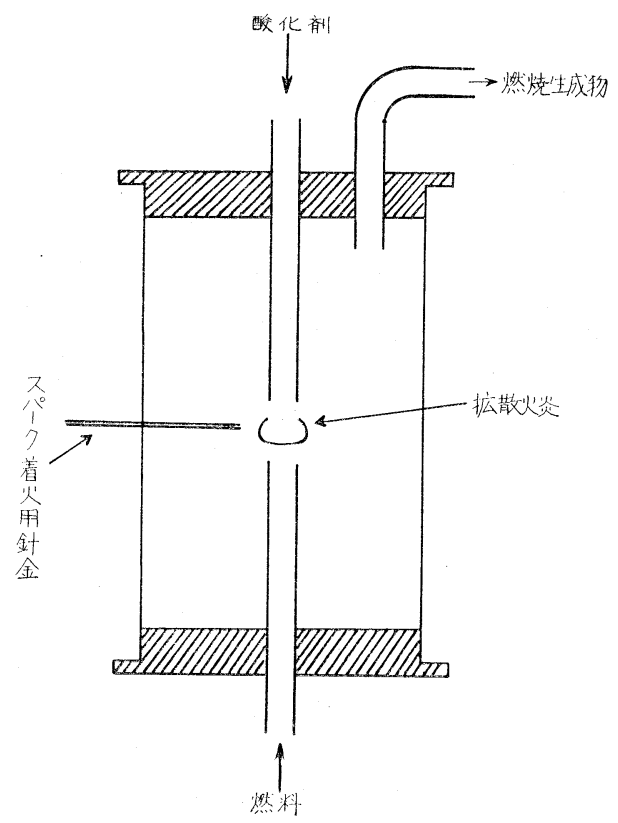

第1図 対向流拡散火炎バーナ

この場合バーナ出口の速度分布が一様でないため，形 成された火炎活平らでなく，しかも吹き消えは火炎の 中央部から抗こるので，たとえ火炎の周困部が輸状に 残つていても，中央部の火炎が消えた場合を火炎の吹 き消えと判定し，この時の火炎中央部の単位面積あた りの燃料之酸化郕の平均質量流 $\left(\mathrm{g} / \mathrm{cm}^{2} \cdot \mathrm{sec}\right)$ を火炎の 強さ (flame strength) と定義し, 各種気体燃料と酸 化㓮の組合せについてf.s. を測定し，さらにf.s.に およぼす圧力, バーナの寸法, 流れの $R_{e}$ 数の影響走 調べた ${ }^{10111}$ 。Zeldovich や Spalding の解理論析によ ると，拡散火炎が保持される燃料の最大質量流速は， その燃料と酸化剮の予混合気中を伝播する火炎面の前 位時間, 単位面積あたり消費される燃料の質量 $m_{f} S_{l}$ に比例与号が ( $S_{u}$ ：燃焼速度， $\rho$ ：尒混会父の密度， $m_{f}$ : 予混合気中の燃料の質量分率 $)^{(6) 7)}$, 第 2 図の f.s. の測定結果はこの関係が正しいことを示している。第

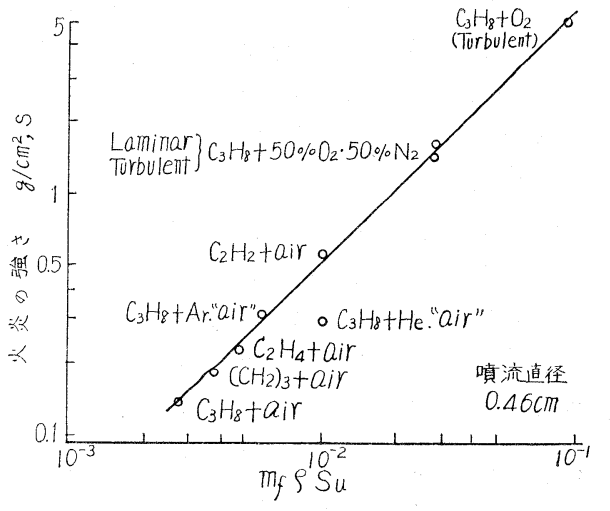

第2図 火炎の強さと $\boldsymbol{M}_{f} p \boldsymbol{S}_{u}$ との関係

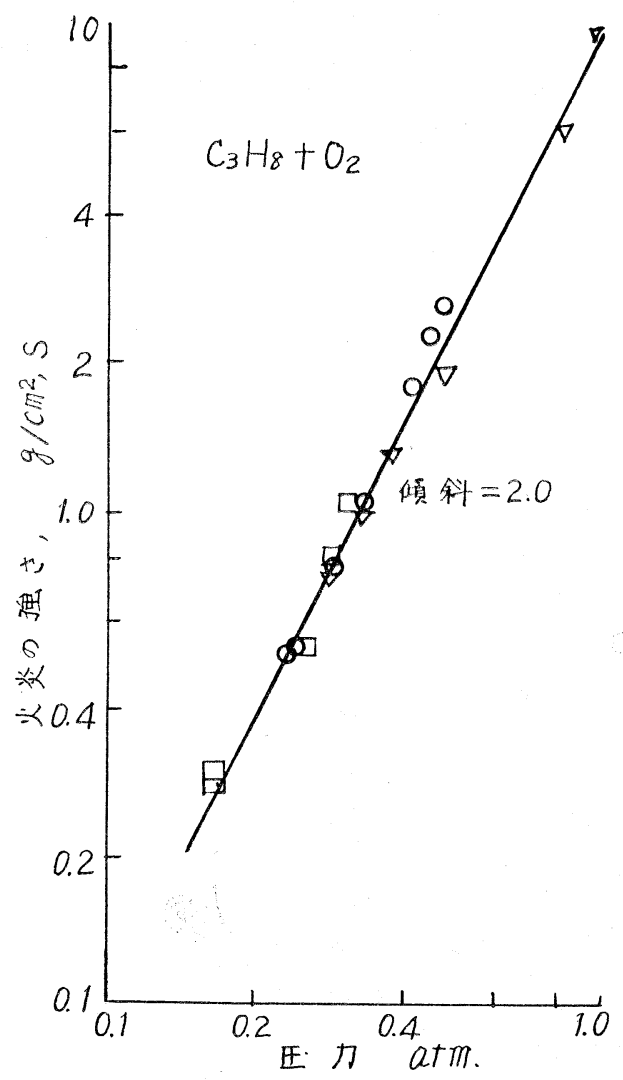

第 3 図 火炎の強さと圧力との関係

3 図はプロパンと酸素の組合せについての f.s. の測 和結果と压力との関係索示している。理論解析による とこの図に晾ける直線の傾斜はほぼ応次数を表わ寸 ものとされているが，消炎距離の実験称ら求的られた 
プロパン・酸素混合気の反応次数 2.1 亿非常に近いこ とがわかる。これらの実験結果から，f.s. は火炎反応 の global な反応速度を示す適切なパラメタであるこ とが理解できるし，また理論的にもこのことは支持さ れている12)。

このPotter らが用いたバーナは f.s. を測定するこ とには成功したが, 火炎形状が平らでないため,たとえ ぼ光学的方法を応用して火炎の微細構造を調べるのに は適していない。非常に反応性に富み予混合すること が困難な燃料・酸化剤の組合せや，燃焼速度が速く平 らな予混合火炎を保持するのが困難な燃料・酸化剤の 組合せについて，対向流拡散火炎を用いてその火炎構 造や反応機構を調べる目的で, Pandya とWeinberg は Potter らのバーナを根本的に改良し，円管内にガラ ス球を詰め，さらに円管出口に整流用マトリックスを つけ, 燃料, 酸化剂とも十分整流して流出させ, 直径 約 $7 \mathrm{~cm}$ 位の平らな対向流拢散火炎をつくることに成功 した ${ }^{13) 14}$ 。彼らは干渉計や deflection mapping などの 光学的測定方法が, この火炎の構造の解析に十分適用 できることを確かめ, さらに熱電対, ナトリウム $\mathrm{D}$ 線 反転法, ガスクロマトグラフイや微粒子追跡法などの 各種の測定手段を用いて，平らな対向流拡散火炎まわ りの流れの様子, 速度分布, スペクトル, 屈折率分 布, 温度分布やガス成分の濃度分布などを詳しく测定 乙, 速度分布や温度分布から火炎を横切っての熱発生 率分布を求めているが，この刘向流拹散火炎では熱発 生領域の巾が予混合火炎の約10倍にも達していること を確かめている。このことは対向流拡散火炎が常圧で の高温の kinetics や速、燃焼速度をもつた混合気の火 炎反応の研究に有力な手段を提供するものであるとい うことを示している。Place とWeinberg は早速この 火炎を用い, 火炎に垂直に電場をかけ，火炎の発光， 炭素形成の割合や䊀子の大きさにおよぼす電場の強さ やイオン流の影響を調べている ${ }^{15)}$ 。平らな刘向流払散 火炎はこのように火炎構造や反応機構を調べるのにき わめて有力な手段を提供してくれるが，平らな火炎を つくるためには, 燃料と酸化剂の流量就よびバーナ口 の間隔の制御をしなければならず，面倒である。また 形成された火炎の空気力学的構造もやや複雑で, 時に は二つの岐点があらわれる場合もある。

対向流拡散火炎の一つの例として, 一様な空気流中 におかれた多孔質の円筒の表面から燃料ガスを一様に 吹き出した場合に山简の前方淀为点附近に形成されを 対向流搪散火炎について, 最近著者の一人によつて奏

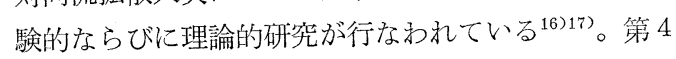

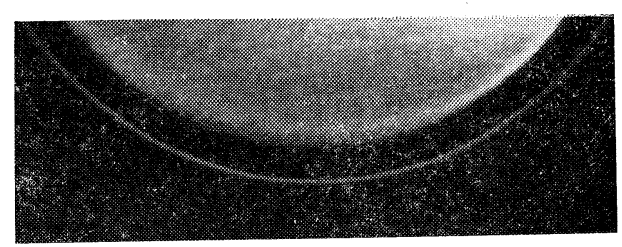

\section{第 4 図 円筒の前方淀み領域に形成} された対流拡散火炎

図写真に示すようにこの火炎は平らではないが，円筒 状の完全な二次元火炎であり，かつ岐点は必ず円筒表 面と火炎との間にあって流れの場も平らな火炎に比べ てむしろ単純であり，さらに火炎をつくるための実験 操作もきわめて簡単であるといら利点がある。まず形 成された火炎の位置 (円筒表面から火炎までの距離 $y_{*}$ ), 火炎の安定限界, 温度分布や流れの場におよぼ す一様空気流の流速 $V$, 燃料ガス吹き出し速度 $v_{w}$, 冈筒の半径 $R$ や燃料ガス成分のような空気力学的, 化 学的パラメタの影響が実験的に調べられた。第 5 図に 安定曲線の測定結果の一例を示す。 $v w$ が減るか, あ

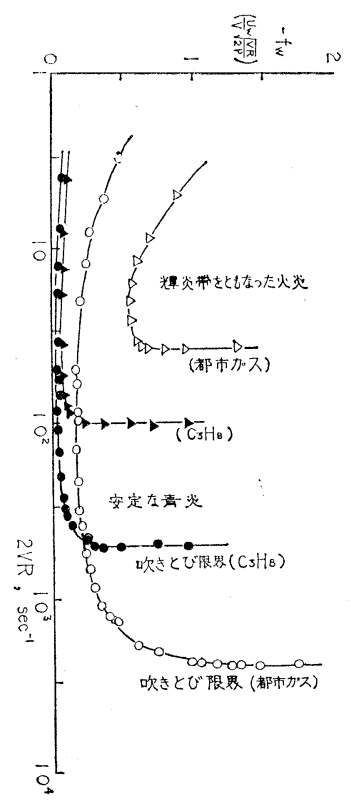

\section{第 5 図 円筒の前方淀み領域に形成され た対向流拡散火炎の安定曲線}

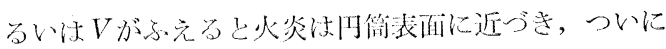
前方淀办領域から吹きとび, 突然に後流形り火炎に遷

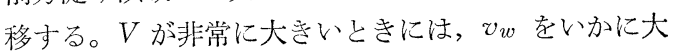


きくしても火炎はこの領域に保持されず，火炎が保持 されるための臨界岐点速度勾配 $(2 V / R)_{c}$ が存在す る。岐点速度勾配 $2 V / R$ はいわ沛る reaction frequency と同じ次元 (時間 $^{-1}$ )をもつており，かつ(2 $V / R)_{c}$ は然料の種類によつて異なるので, この蹞界 岐点速度勾配は各燃料之空気との組合せに対する反応 速度の目安を示していると考えられる。よつてこの值 は Potter らが用いた火炎の強さの代りに用いること のできるパラメタである。な拉 $V$ が非常に小さく $v_{w}$ がかなり大きくなると，火炎の巾は厚くなり，火炎帯 の燃料側に黄色の輝炎ができはじめる。

測定された火炎の位置, 温度分布や流れの場の各種 パラメタに対する依存性は，簡単な火炎面模型を用い て行なわれた解析結果と非常によい一致を示してい る。このことは, この火炎の流体力学的特性が非常に 単純であることを示している。またこの火炎は非常に 安定で，かつ完全に二次元形状をしているので，光学 的あるいは分光学的測定によつて火炎の微細構造を研 究するのに適しているし，また臨界岐点速度勾配の測 定によつて反応速度の目安を求めることも可能であ る。

\section{2. 超音速燃焼}

将来の極超音速の長距離航空機用エンジンとして, また大規慔の宇宙探究用大型口ケットの回収们能なブ 一スタとして，非常に高いマッ八数で飛行可能なairbreathing エンジン，すなわち極超音速ラムジェット エンジンが最近非常に注目を浴びている。この airbreathing エンジンが化学ロケットモータに比べて優 れている点は, 飛行体は燃料だけを持参し, 燃燒に必 要な酸素は大気中から取り入れることであり，そのた め比推力は化学口ケットモータに比べて一桁近く大き くなり,かつ推進剤やタンクの重量, ひいてはエンジ ン全体の重量やその大きさが著しく減少することであ る。2 6 程度の比較的低いマッ八数の飛行を対象に したラムジェットエンジンにおいては, エンジンに入 つた空気流は亚音速に減速され, 静圧や温度は上昇 し，ここで燃料が噴射され，西音速空気流中で燃焼が 行なわれ，燃焼ガスはノズルをとおつて噴出される。

しかしさらに高いマッハ数の場合, 空気流を亜音速 まで減速させると, 燃焼器内の空気流の静圧と温度は 非常に高くなり, 燃焼器そのものの設計が困難になる とともに, 高温のため空気は解離しはじめ, さらに燃 料定この状態で噴射しても, 然料分子もまた解離をお こし, 燃料噴射後の平衡温度はかえつて噴射前よりも 低くなるといら事態がおこる。したつて非常に速い飛
行に対しては, エンジン内での空気流の減速は燃焼器 内の空気の静圧や温度が燃焼に適した状態に保てる程 度にとどめておく必要があり,そのため必然的に燃焼 器内の空気流速は超音速となる。以上のような事情で 超音速燃焼ラムジェットが俄然脚光を浴びるようにな $り^{18119)}$ ，さらにここ数年来, 超音速気流中の燃焼その ものの研究が非常に盛んになつてきた20) 22)。この問 題は現在燃燒研究の一つの大きなトピックスであり, 多くの研究者の関心を集めているが，何分実験を行な らためには大がかりな設備を必要とするので, これま での基礎的実験ですら, 主として二, 三の研究グルー プに限られていた。

超音速燃焼はその燃焼の過程によつて大体三つの型 に分類できるが，燃燒領域をなるべく短かくしょうと する意図のもとに，まず standing detonation wave (stabilized detonation wave とも呼ばれる) を利用す る燃焼方式についての研究からはじまつた。 S. D.W. とは，管の中の予混合気中を伝播する普通の detonation wave とは異なり, 燃焼器内のある定まつた位置 に定常的に保持される detonation wave のことであ り, この場合燃料と空気は上流の比較的低温, 低圧の 状態で予混合されており，そのため予混合されただけ の状態では燃焼が開始されず, 衝撃波通過によつて高 温高圧となり，短い着火おくれ期間を経て燃焼が急速 におこる。このためには強い衝撃波が必要となる。

この種の研究は主として Michigan 大学の Nicholls のグループによつて行なわれてきたが，まず S. D.W. が実現される可能性を調べるために，S. D. W. が維持

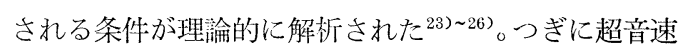
噴流中に形成される垂直衝撃波（Mach disc）につい ての空気力学的研究を経て ${ }^{27)}$ ，1958年はじめて第 6 図 に示すような形状の水素・空気混合気の垂直 S.D.W.

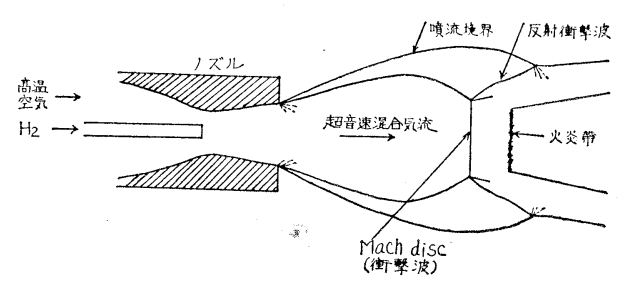

第 6 図 重直な Standing detonation wave

が Nicholls グループによつて実験的につくり出され た2930)。また同年にこれとは独立に Fairchild Engine and Aircraft Corp.の Gross らによつて一様な超音 速流中にできたマッハ反射衝撃波を利用した垂直 $\mathrm{S}$. 
D.W. が観察された ${ }^{28)}$ 。それ以後, 垂值 S. D.W.の

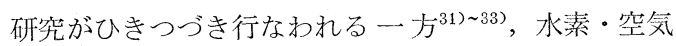
混合気の超音速流中の楔によつて保持された斜めのS.

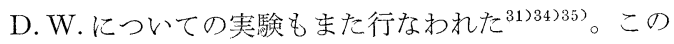
二つの型の S. D. W. は同心性質のものであり，(1) 衝撃波背後で着火がおこるためにはある最小温度が必

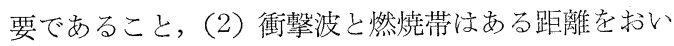
てはつきり分れており，この距離は温度が上昇すると 急激に減少する，(3) 垂直 S. D. W. の数例を除き, 燃焼の存在は衝撃波に影響をおよぼさないことなどが 確かめられた。それ故にこの S. D. W. はむしろ衝撃 波によつて誘発される燃焼といらべき性質のもので, 着火おくれには高温での混合気の chemical kinetics が重要な役割を果していることがわかる。S.D.W.の 研究は主として着火おくれ時間（衝撃波と燃燒带の距 離）の測定に重点が置かれたが，測定結果は理論解析 結果とかなりよい一致を示している ${ }^{34) 36}$ (第7 図)。こ

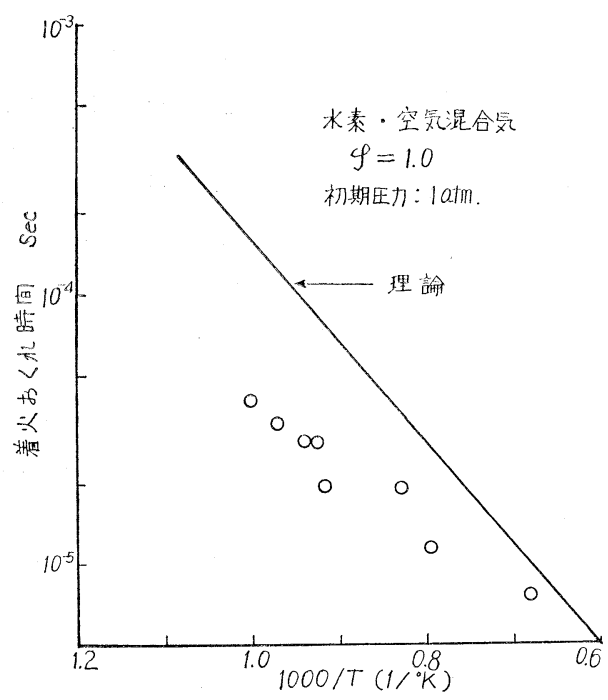

第 7 図 着火おくれ時間の理論値と実験値

のことから逆に，S. D. W. は混合気の chemical kinetics 調べるのに非常に有力な手段を与えてくれる ことがわかる。なお S. D. W. の実験方法の変形とし て, 静止している混合気中にナイロンやプラスチック の球を極超音速で打ちこみ，この球の先頭にできる衝 撃波によつて誘起される然㜔を用いる方法がある 38)。

超音速然焼の第二の形式は，パイロッ火炎を用い て子混合超音速気流を着火させ，火炎を安定化させる
方法である。この方法は，飛行マッ八数が 3 〜 程度 で比較的低く, 燃焼器内の超音速空気流の圧力や温度 も政分高くく，そのため燃料を噴射しても自発 着火しない場合とか，化学反応がおそい混合気流の場 合に用いられるもので, 着火や火炎の安定化は, 主と してパイロット火炎からの熱輸送過程によつて制御さ れる。この問題は亜音速流のパイロット火炎による着 火や火炎の安定化と本質的に同じものであり ${ }^{39)}$, 境界 層近似を用いて解析を行なうことができ22740)，また火 炎の抾がりも比較的容易に解析できるが ${ }^{41242)}$, 実験は Gen. Appl. Sci. Lab. で行なわれているだけで, 現 在までのところ一篇の報告があるにすぎない40)。この 実験では水素・空気混合気流 $(M=1.5)$ 中の火炎の伝 播角度, 火炎の附着距離, 火炎を横切つての静圧, 全 圧，全温度分布などを測定しているが，計算結果とよ く一致することが確かめられている。なおこの燃焼方 武においては，燃焼領域で衝撃波は生じない。

超音速燃焼の第三の形式は，超音速拡散火炎を用い る燃焼方式である。飛行マッ八数が 6 以上になり, 燃 焼器内の超音速空気流の静圧や温度も十分高くなる と，化学区忘速度は非常に速くなり，燃料を噴射する と等気との混合によつて自然着火し，燃料と空気の乱 流拡散によつて燃焼過程が制御される超音速乱流拡散 火炎が衝撃波をともなわないで形成される。この方式 による超音速然焼の研究は主として Polytechnic Inst. of Brooklynの Ferri を中心とするグループによつで ここ数年来精力的に行なわれている。乱流混合の場合 には，混合過程が十分速く，非常に速い流れにおいて も燃焼器の長さを実用的な長さに抑えることができ， またこの方式を用いたラムジェットエンジンは，空気 取入口やノズルの形状を変えることなしに広いマッハ 数範国にわたつて良い性能を保持することができるの で，Ferri らはこの燃焼方式を超音速ラムジェットエ ンジンの本命と考えているよらである ${ }^{2122) 。 ~}$

この燃焼方式では超音速空気流と燃焼噴流との乱流 混合が重要な役割を果しているので，この燃焼方式に ついての研究はまず異種の気体間の超音速乱流混合の 研究が空気力学の立場から行なわれ，解析が試みられ るとともに，水素，ヘリウム，アルゴン，炭酸ガスと 空気との間の超音速乱流混合の実験が行なわれた ${ }^{22) 433}$ 〜5)。濃度や速度分布などが測定されているが，乱流 輸送係数を適当にとれば，測定結果は解析結果とよく 一致することが確かめられている。一方然焼をともな つた場合の研究は，ほとんど然料として水素を用いて おり, global な化学反応を考えた場合の計算 ${ }^{46) 47}$ や素 
応をも詳しく考虑した解析が行なわれている(33)48749)。 実験では主として，火炎着火距離，着火誘導時間，火 炎の形状や噴流中心軸に沿つての岐点温度などが測定 されているが，燃料噴流速度 $u_{j}$ と空気流速度 $u_{e}$ と の比, $u_{j} / u_{e}$ ，が現象を支配する重要なパラメタである

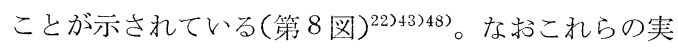
験とは独立に, 燃焼空壁のスリットから $M=3 \sim 5$ の 超音速空気流中に液体燃料を吹き出した場合の燃焼の 実験も行なわれている50)。

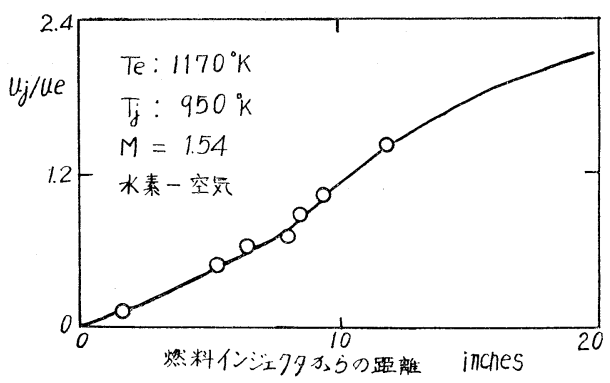

第 8 図火炎着火距離

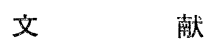

1) T. von Kármán, L'Aerotecnica, 33, 1, 80/86 (1953)

2) 辻 㕕, 日本機械学丟誌, 63,499, 1171/1178 (1960)

3) 辻広, 日本航空学丟誌, 10,99, 122/133 (1962)

4) D. B. Spalding, Fuel, 32, 2, 169/185 (1953)

5) D. B. Spalding, Fourth Intern. Symp. on Combustion, 847/864(1956)

6) Y. B. Zeldovich, Zh. Tekh. Fiz., 19, 1199 (1949), NACA TM 1296 (1951)

7) D. B. Spalding, Fuel. 33, 3, 255/273 (1954)

8) F, E. Fendell, Journ. Fluid Mech., 21, 2, 281/303 (1965)

9) A. E. Potter, Jr. and J. N. Butler, $A R S$ Journ., 29, 1, 54/56 (1959)

10) A. E. Potter, Jr., S. Heimel and J. N. Butler, Eighth Intern. Symp. on Combustion, 1027/ 1034 (1962)

11) E. Anagnostou and A. E. Potter, Ninth Intern. Symp. on Combustion, 1/6 (1963)

12) D. B. Spalding, ARS Journ., 31, 6, 763/771 (1961)
13) T. P. Pandya and F. J. Weinberg, Ninth Intern. Symp. on Combustion, 587/596 (1963)

14) T. P. Pandya and F. J. Weinberg, Proc. Roy. Soc., London, A, 279, 1379, 544/561 (1964)

15) E. R. Place and F. J. Weinberg, Proc. Roy. Soc., London, A, 289, 1417, 192/205 (1966)

16) H. Tsuji and I. Yamaoka, Inst. Space and Aero. Sci., Univ. of Tokyo, Report No. 404 (1966)

17) H. Tsuji and I. Yamaoka, to be presented at the Eleventh Intern. Symp. on Combustion, Berkeley (1966)

18) R. J. Weber and J. S. Mackay, NACA TN 4386 (1958)

19) W. H. Avery and G. L. Dugger, Astronautics \& Aeronautics, 2, 6, 42/47 (1964)

20) G. L. Dugger, ARS Journ., 27, 11, 819/827 (1959)

21) A. Ferri, Astronautics \& Aeronautics, 2, 8, 32/37 (1964)

22) A. Ferri, Jnurn. Roy. Aero. Soc., 68, 645, 575/597 (1964)

23) J. Rutkowski and J. A. Nicholls, Proc. Gas Dynamics Symp. on Aerothermochemistry, Northwestern Univ., Evanston, 243/253 (1956)

24) R. Dunlap, R. M. Brehm and J. A. Nicholls, Jet Propulsion, 28, 7, 451/456 (1958)

25) R. Siestrunck, J. Fabri and E. Le Grives, Fourth Intern. Symp. on Combustion, 498/501 (1953)

26) R. A. Gross, AIAA Journ., 1, 5, 1225/ 1227 (1963)

27) T.C. Adamson, Jr. and J. A. Nicholls, Journ. Aero/Space Sci., 26, 1, 16/24 (1959)

28) R. A. Gross, ARS Journ, 29, 1, 63/64 (1959)

29) J. A. Nicholls, ARS Journ., 29, $8607 / 608$ (1959)

30) J. A. Nicholls, E. K. Dabora and R. L. Gealer, Seventh Intern. Symp. on Combustion, 766/772 (1959)

31) R. A. Gross and W. Chinitz, Journ. Aero/ Space Sci., 27, 7, 517/524 \& 534 (1960)

32) J. A. Nichlls and E. K. Dabora, Eighth Intern. Symp. on Combustion, 644/655 (1962)

33) J. A. Nicholls, Ninth Intern. Symp. on Co- 
mbustion, 488/498 (1963)

34) P. M. Rubins and R. P. Rhodes, Jr., AIAA Journ., 1, 12, 2778/2784 (1963)

35) P. M. Rubins and T. H. M. Cunningham, Journ. Spacecraftand Rockets, 2, 2, 199/205 (1965)

36) I. N. Momtchiloff, E. D. Taback and R. F. Buswell, Ninth Intern. Symp. on Combustion, 220/230 (1963)

37) F. W. Ruegg and W. W. Dorsey, Journ. Res. NBS. 66C, 1, 51/58 (1962)

38) H. Behrens, W. Struth and F. Wecken, Tenth Intern. Symp. on Combustion, 245/252 (1965)

39) H. Tsuji, Aero. Res. Inst., Univ. of Tokyo, Report No. 357 (1960)

40) S. Slutsky, J. Tamgno and N. Trentacoste, AIAA Journ., 3, 9, 1599/1605 (1965)

41) M. M. Gibson, Tenth Intern. Symp. on Combustion, 1179/1185 (1965)

42) L. N. Khitrin, S. A. Gol' denberg and I. N. Sundukov, NASA TT F-79, 104/111 (1962)

43) A. Ferri, P. A. Libby and V. Zakkay, Proc. ICAS, Third Congr., Stockholm, 1089/1155 (1962)

44) V. Zakkay, E. Krause and S. D. L. Woo, AIAA Journ., 2, 11, 1939/1947 (1964)

45) J. M. Forde, Aero. Quart., 16, 4, 377/387 (1965)

46) P. A. Libby, ARS Journ., 32, 3, 388/396 (1962)

47) J. A. Schetz, "Supersonic Flow, Chemical Processes and Radiative Transfer" edited by D. B. Olfe and V. Zakkay, The Macmillan Co., New York, 79/91 (1964)

48) V. Zakkay and E. Kranse, ibid., 3/29.

49) A. Ferri, G. Moretti and S. Slutsky, Journ. Soc. Ind. Appl. Math., 13, 1, 229/258 (1965)

50) F. S. Billing, Tenth Intern. Symp. on $\mathrm{Co}^{-}$ mbustion, 1167/1178 (1965)

\section{II 火 炎 構 造}

一般に火炎構造（Flame structure）という言葉に は, 炎中の温度や流速のよらな物理量の測定に基礎を おいた熱構造 (Thermal structure), 流体構造(Aerod-

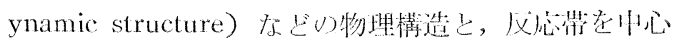
とした火炎内の资定打よび不灾定化学種，さらに䉓湖 をもつた化学種などの化学量の測定にもとゔく化学構
造功含まれる。その点，この研究分野の範井は非常に 広いが，前者の研究は最近はごく少ないのでここでは 定常的な水素や炭化水素の火炎中における化学種やイ オン，炭素粒子などの分布の問題を中心に，またその 時期を1964年以降と考えて，これら研究の最近の動向 を記してタたいと思う。

\section{1. 火炎中の化学種の分布}

いらまでもなく火炎構造を調べるためには，伝ぱ火 炎を用いるよりも定常的にバーナー上に安定化された 炎を用いる方が容易である。したがつて，火炎構造の 研究の進歩の一半は，その目的に適したバーナ一の開 発にかかつているといつてよく，実際にも予混炎の場 合1950年頃 Egerton とPowling によつて工夫された平 面炎バーナー (Flat flame burner) が以後の火炎構造 の研究に貢献したことはよく知られている所である。 一方，拡散炎に対しては，平面炎バーナ一は利用でき ないので従来は Parker-Wolfhard 型の燃料と酸素の 流れの境界面に火炎をつくる一次元バーナーが多く使 用されてきたが，1963年に Pandya と Weinberg'1) より速度分布が一様な燃料と酸素の流れを逆向きにぶ つけ，その境界に一次元の火炎をつくる向流拡散炎バ ーナー (Counter flow diffusion burner) が考案され て以来拡散炎の構造の研究にはこれの利用が増してき た。このバーナーの特性に関してはその後前記の考案 者たらにより，エチレン火炎について詳細に検詩され ているが2), その結果によると温度, 流れ, 化学組成 などの対称性はかなりよく，昖散炎の研究には優れた バーナーであることがわかる。参考として第 1 図には 温度分布の, また第 2 図には速度分布の一例を示し

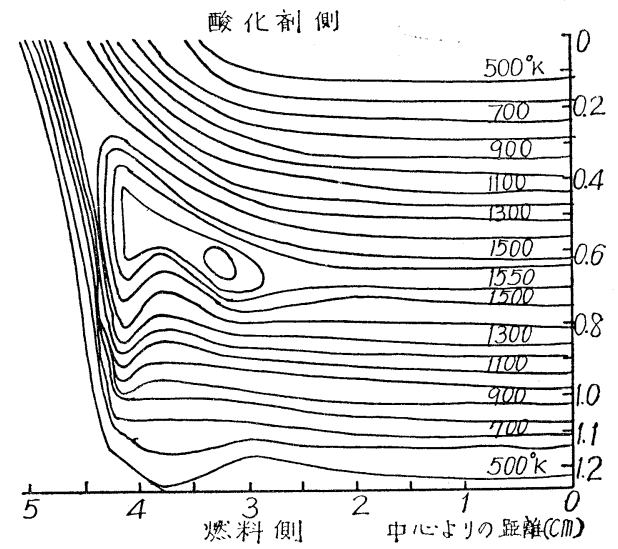

第1図向流拡散炎内の等温度曲線

[Pandya, Weinberg, (1964)] 


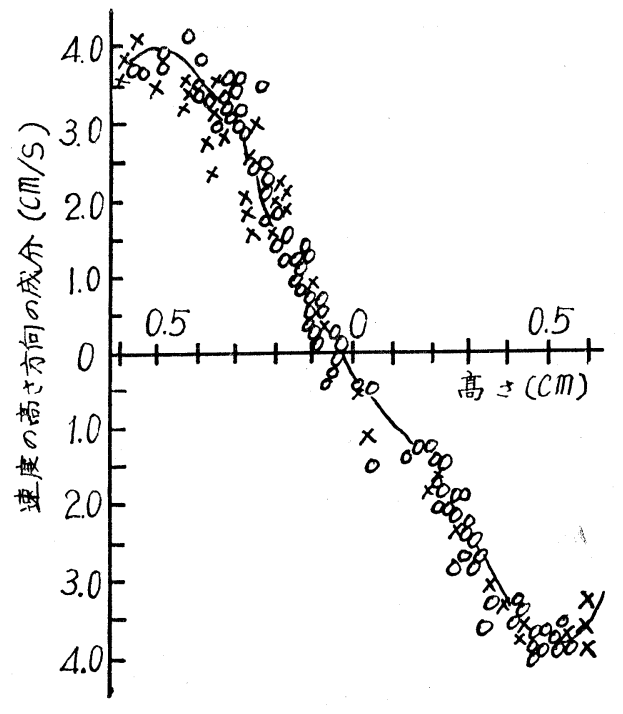

\section{第 2 図 向流拡散炎内の流れ方向の流速分布} [Pandya, Weinberg, (1964)]

た。なお, Ibiricu と Gaydon ${ }^{3)}$ はこの型のバーナー を用いてエチレン，メタン，水素火炎に対する八口攵 ン系抑制郕の作用を調べ，また过と山岡 ${ }^{4)}$ は流孔に関 するパラメターを変えた場合の火炎の安定限界その他 の問題を検討している。

一方, 火炎中の各種の物理量や化学量を測定する方 法も一段と進歩し，とくに化学種の測定に対する飛行 時間型質量分析計 (TOF mass-spectrometer) の使用 は著るしく普及してきた。しかし，この装置において も1気圧以上の火炎からの試料の採取にはなお問題が

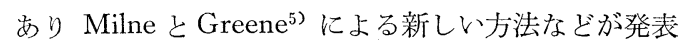
されている。

また, 最近は電子スピン共鳴 (ESR) を炎中のラジ カルや原子の測定に利用する試みも行なわれ, Westenberg と Fristrom ${ }^{6)}$ は $\mathrm{C}_{2}$ 炭化水素の低圧平面炎中 の水素原子と酸素原子の分布をこれによつて求めてい る。きれいな結果がでているので，その一つを第 3 図 に示した。さらに, 燃焼ガス中の赤外発光スペクトル から温度と化学種の濃度も決める方法》 や炭酸ガスの 䟴度を分光的に求める方法8) なども提案されている。

ところで, 平面炎バーナーを用いて火炎中の反応機 構を研究した論文は最近も頗る多いが，いわ师る素反 応については別項に記されるはずなので，ここでは炎

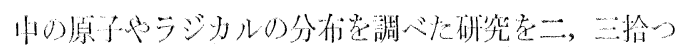
てみると，まず Hinck, Seamans, Vanpee, Wolf$\operatorname{hard}^{9)}$ は水素, エチレンなどと酸素の大きな低圧火炎
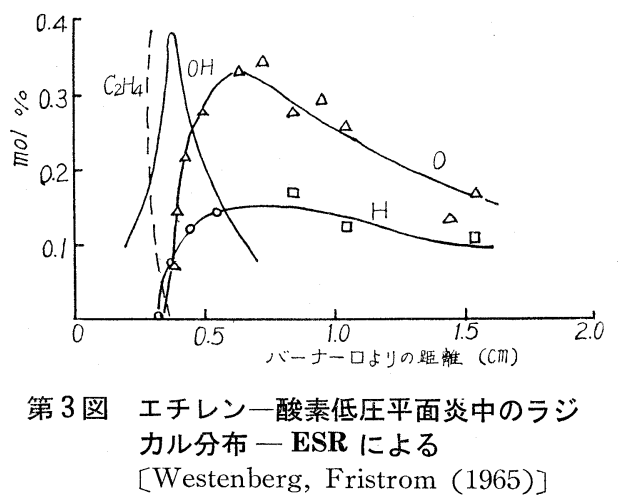

中の $\mathrm{OH}$ の発光を改めて測定し, この化学発光は反応 帯のみならず然燒ガス中でも生ずることを認め, また Fenimore とJones ${ }^{10)}$ ( 酸水素炎におけるラジカルの 再結合にもとずく発熱を炎の熱構造との関連において 論じている。このほか Wilson, Jr. ${ }^{11)}$ は臭化メチル を添加したメタン一酸素混合気の火炎構造を研究し, それをもとに添加剤の抑制作用を検討したが，彼の結 論によると抑制郕の作用は Preignition zone を拡げ, そこにおけるラジカルと抑制剂の反応を容易にするこ とにあるという。な押，炭化水素やエーテルの低温然 焼についても最近また論文が增してきた傎向にあり， Agnew ら ${ }^{12)}$ はジエチルエーテルー空気の二段平湎 炎の火炎構造を調べ, 冷炎を拌なら二段燃焼にはアル デヒド，アルコール，酰酸，などのような含酸素物質 が重要で,また二段目の反応にはメタンの生成が大き な役割を果たしているとした。そして,この結果はア セトアルデヒドなどの二段火炎中の生成物を質量分 析したBradley, Jones, Skirrow, Tipper ${ }^{13)}$ のそれと 含酸素物質が後者の場合過酢酸であることを除いてほ ぼ一致している。第 4 図にはアセトアルデヒド一酸素 火炎中の灾定な化学種分布の一例を示した。このほ か, 二段燃焼についてはシクロヘキサンの泠炎安研究 した Bonner と Tipper ${ }^{14)}$ のものや正へキサンの泠炎 を調べた Sueyasu と Hikita ${ }^{15)}$ の研究などがある。

さて，これまでは普通の気体然料についてのもので あつたが，特殊な燃料の火炎構造に関するものも最近 はかなり多く，たとえば Levy とMerryman ${ }^{16)}$ は硫 化水素一酸素混合気の平面炎の微細構造を研究し, $\mathrm{SO}$ が $\mathrm{SO}_{2}, \mathrm{SO}_{3}$ と階段的に酸化してゆく過程を明ら かにした。彼らによると, $\mathrm{SO}_{3}$ は $\mathrm{SO}$ の酸化の結果 として始め前火炎钼 (pre-flame zone) で生ずるが, これは反応带中で一牌減り, そのあとで再び酸素原子 による $\mathrm{SO}_{2}$ の酸化の結果として増加するという面白 


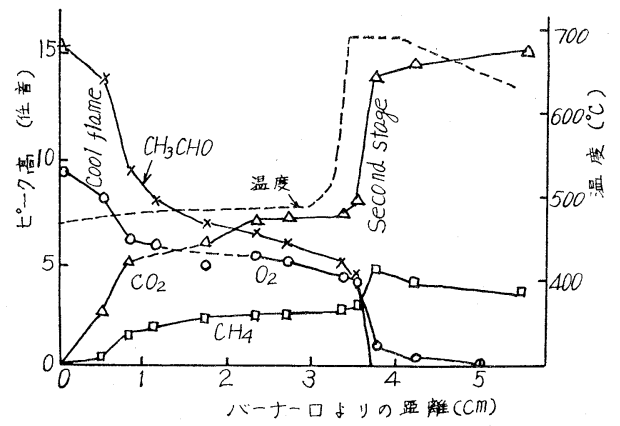

第 4 図 アセトアルデヒド一酸素二段火炎の 生成物濃度分布

[Bladley, Jones, Shirrow, Tipper (1965)]

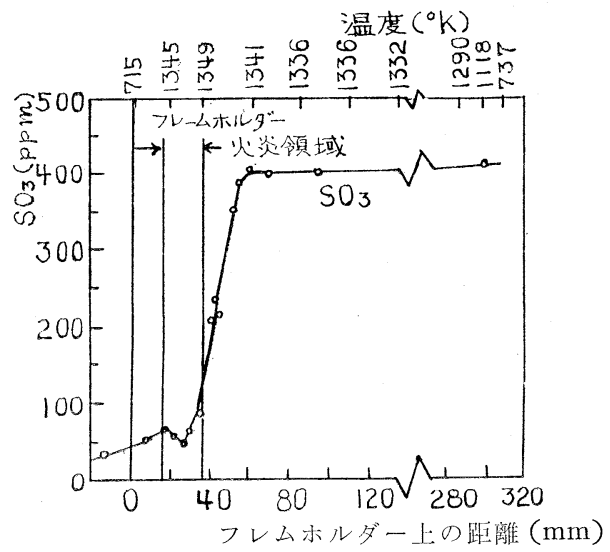

第 5 図 硫化水素一酸素火炎中の $\mathrm{SO}_{3}$ の分布 [Levy, Merrymen (1965)]

い経過を示す。この様子は第 5 図に例示した。また， アルキルアルミニウム，とくにトリメチルアルミニウ ムの然焼の研究はここ一，二年かなり目につくが，火 炎構造の見地からするとVanpee, Hinck, Seamans ${ }^{17)}$ のものが面白い。彼らはこのものと酸素の火炎につい て安定限界然燒温度, スペクトルなどの燃焼特性安調 べこの炎はアルミニウムの反応による第一の反応 带と炭化水素にもとずく第二の反応带の二重反応带学 もち, 全体としての燃燒速度は後の方, つまり炭化水 素の反忘により支配されていて，アルミニウムは単に 熱を供給するにすぎないと結論した。第 6 図にはこの 場合の発光強度の位置による変化を示したが，これか ら二つの反応带があることが一応了解されると思ら。

2. 火炎中のイオンの分布

火炎中のイオンに関する研究は1963年項までに大き

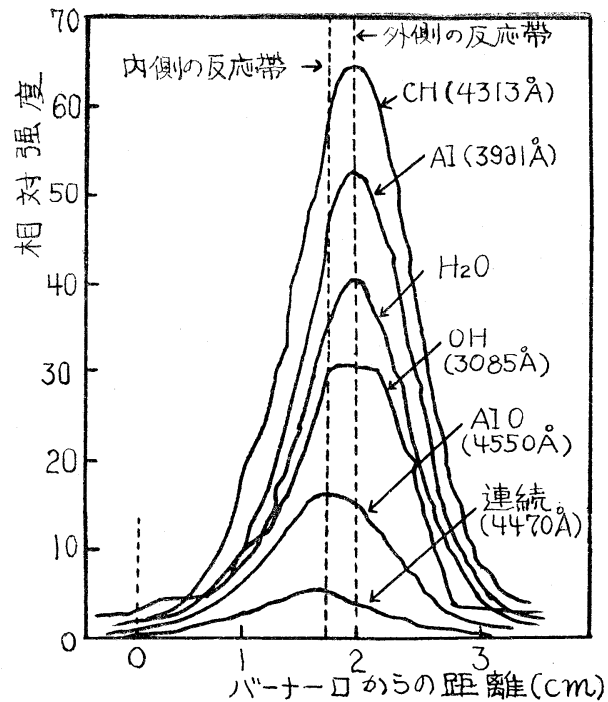

第 6 図トリメチルアルミニウム一酸素火 炎の発光強度の分布

[Vanpee, Hiuck, Seamans (1965)]

な進歩をとげ，炎中の正イオンとしては $\mathrm{H}_{3} \mathrm{O}^{+}$が最も 多く，このイオンの生ずる過程としては

$\mathrm{CH}+\mathrm{O} \rightarrow \mathrm{CHO}^{+}+e^{-}, \quad k_{1}=3 \times 10^{-12} \mathrm{~cm}^{3} / \mathrm{sec}$.

$\mathrm{CHO}^{+}+\mathrm{H}_{2} \mathrm{O} \rightarrow \mathrm{CO}+\mathrm{H}_{3} \mathrm{O}^{+}, \quad k_{2}=7 \times 10^{-9} \mathrm{~cm}^{3} / \mathrm{sec}$ また再結合反忘としては

$\mathrm{H}_{3} \mathrm{O}^{+}+e^{-} \rightarrow \mathrm{H}_{2} \mathrm{O}+\mathrm{H}, k_{3}=2.3 \times 10^{-7} \mathrm{~cm}^{3} / \mathrm{sec}$.

が有力であることがわかつてきた ${ }^{18)}$ 。さらに炎中のイ オンを測定する方法としてもラングミュア一挆針法を 始めとして，マイク口波吸収法(減衰法と共振法), 質 量分析法, さらにはサイクロトロン共振法にいたるま で各種の方法が出揃つた感がある。ところで, それ以 後のこの分野における研究はもつぱら1964年の第10回 燃焼シンポジウムに集まつているように思われるが， これら老眺めてみると，この分野の研究の興味は従来 電子と考えられていた負イオンの同定の問題やイオ ン一分子反応，イオン一固体 (液体) 粒子間の相互作用 を含めた火炎中のイオンの再結合過程の解明に移り, さらに火炎プラズマを利用する場合の常套手段である シーデイング (Seeding) と関連したアルカリ金属のイ オン化やシーデイングした状態における火炎の電気的 特性の測定なども著るしくふえている。以下ここでは とくに基礎的なイオン化現象の物理的, 化学的な研究 は除き，普通の火炎奆対象しした最近の研究の二，: 学紹介することにする。

まず, Calcote, Kurzius, Miller ${ }^{19)}$ 低低武炭化水 
素火炎中のイオンを質量分析とラングミュア一探針法 により測定し，正イオンとしては $\mathrm{H}_{3} \mathrm{O}^{+}$のほかに $\mathrm{C}_{3}$ $\mathrm{H}_{3}{ }^{+}$が多く存在寸常こと, また負イオンとしては $\mathrm{O}^{-}$, $\mathrm{OH}^{-}, \mathrm{C}_{2}^{-}$, などが支配的であるととな゙要認め，さ らに負イオンは $\mathrm{C}_{3} \mathrm{H}_{3}{ }^{+}$の生成ののらに現われること を見出した。この結果はアセチレンやエチレンと原子 状の酸素の反応に䇽いて Fontijn, Miller, Hogan20) の得たものと大体一致しているが，一方，Feugier と Van Tiggelen ${ }^{21)}$ は，上記の人々の得た負イオンは火 炎中に存在はするが量は少なく, むしろ $\mathrm{C}_{2} \mathrm{H}^{-}$や $\mathrm{CO}_{3}$ $\mathrm{H}_{2}{ }^{-}\left(\mathrm{CH}_{2} \mathrm{O}+\mathrm{O}_{2}^{-}\right), \mathrm{CO}_{2} \mathrm{H}_{2}{ }^{-}\left(\mathrm{CH}_{2} \mathrm{O}+\mathrm{O}^{-}\right)$が多いとい う結論を得ている。両者は火炎の条件, とくに圧力や 温度が多少異なるので，そのいずれが確かであるかは 今後の研究に待たなければならないが, 第7 図には Calcote らの与えた圧力 $1.0 \mathrm{mmHg}$ の理論混合比にあ るアセチレン一酸素火炎中の負イオン分布を与えてお いた。また負イオンの生ずる位置についても calcote

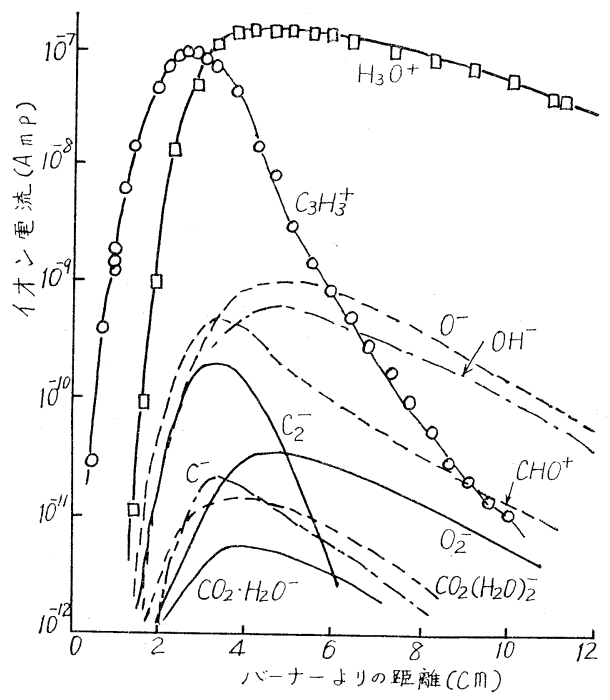

第7図 アセチレン一酸素火炎中のイオンの分布 [Calcote, Kurzius, Miller (1965)]

らとは逆にこれらは炎の予熱帯ないしは反応帯の初期 にあらわれ，燃焼生成ガス中にはほとんど存在しない といら結果が Knewstubb褯によつて提出されている ので，前記の結果が決定的ともいえない。なお，正イ オン濃度と熱発生速度の関係は 1 気圧のメタン一空気 平面炎について Wortberg ${ }^{23)}$ によつて測定され，第 8 図のように初期はよく一致することが確かめられた。

つぎに，イオンの再結合やイオンと他の粒子，分子

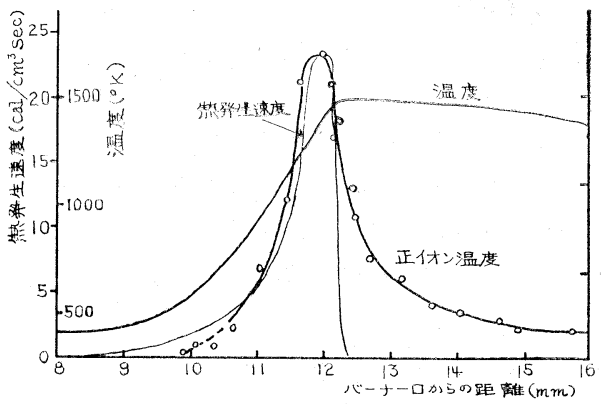

\section{第 8 図メタン一空気平面炎中の正イオ ン濃度と熱発生速度}

[Wortberg (1965)]

との反応については, Franklin と Manson ${ }^{24)}$ はメタン 一酸素混合気中のイオン分子反応を, Soo と Dimick 25)はイオン化されたガスによる固体粒子の带電の問題 を, また Biondi, Connor, Weller, Kasner ${ }^{26)}$ は二 原子イオンの再結合の速度をそれぞれ取扱つている。 さらにSohofield と Sugden ${ }^{27)}$ は水素一空気火炎中に 添加したアルカリおよびアルカリ土類金属のイオン化 を詳細に検討し，これら添加物のイオン化は反応帯の 後方で起こること, またその再結合反応はたとえばカ リウムの場合 $\mathrm{K}^{+}+e^{-}+(\mathrm{M}) \rightarrow \mathrm{K}+(\mathrm{M})$ のよらな形式の ものであることを明らかにした。第 9 図には添加金属 イオンの生成時期が $\mathrm{CH}_{3}{ }^{+}$の生ずる反応曼より後であ ることを示す一例を図示した。

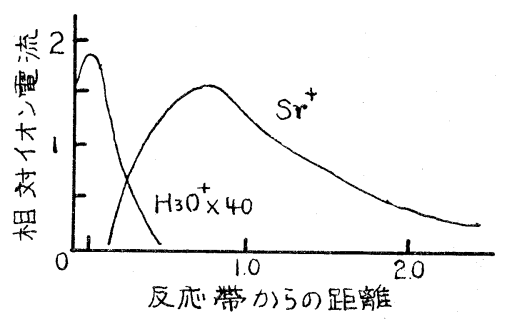

第9図 ストロンチウムを加えた水素一 空気火災中の $\mathrm{Sr}^{+}$の分布

[Schofield, Sugden (1965)]

このほか，実験技術的な閣題としては，Borgers ${ }^{28)}$ は高周波共振法 (High frequeney resonance method) の特長をマイクロ波吸収法と比較して論じ，この方法 は重いイオンや電子を把えるのに適当していることを 主張し，また Travers とWilliams ${ }^{29)}$ は二本の球型探 針を用いたラングミュアー法を述べ，これを高圧火炎 に適用する場合の修正法を検討している。これらはシ 
ーデイングを行なつた燃焼生成ガス中のイオンを探針 法で測定寸る場合の泠厄い探針の影響苦考察したTu一 rcotte と Friedman ${ }^{30)}$ の研究なととともに火炎中のイ オン分布空実際に測定する場合に有用である。

なお，火炎構造とは直接の関倸はないが，火炎に電 界をかけてイオン電流を取出寸際の限界については Lawton と weinberg ${ }^{31}$ の興味深い研究があるので付 け加えておく。

\section{3. 火炎中の炭素の生成}

火炎中の炭素生成に関する研究が，ここ数年の間に 非常に進歩したとは思えないが，毎年いくつかの論文 が内外の雑誌に発表されている。もともと，この現象 は火炎研究の分野の内でも最も複雑な部類に属し, 古 くから多くの人々に調べられているにもかかわらず進 歩のおそい領域のように思われるが，普通のバーナー を用いて生成炭素の分析をしたり，電子顕微鏡による 粒径の測定のようなありふれた方法では，これ以上の 進展は望めそうにないため最近は前記のような新らし いバーナーや測定技術の利用とともに特殊な条件や従 来とちがつた考え方で研究を進める傾向が強いように みえる。以下面白そうなものを二，三拾つてみると， まず Macfarlane, Holderness, Whitcker ${ }^{32)}$ は $\mathrm{C}_{5}$ と $\mathrm{C}_{6}$ の炭化水素を燃料とした 20 気圧にいたる高圧予混 炎を用いて炭素の生成を調べ，多少のバラッキはある が, 炭素量は圧力の $2.5 \sim 3$ 乗に比例して増し, その ときの粒子径は 150 250 ̊̊のもが多いことを見出 した。この結果はこれまで低圧炎の実験は多いが高圧 炎のそれはほとんどないという点で価值がある。ま た, Bonne, Homann, Wagner ${ }^{33)}$ および Homann, Mochizuki, Wagner ${ }^{34)}$ はアセチレン, ベンゼン，ア ルコール，二硫化炭素などの燃料と酸素の低圧平面炎 における炭素生成の過程を TOF 質量分析計を用いて 詳細に追跡し，すすの生成や生長には反応帯中で作ら れる $\mathrm{C}_{4} \mathrm{H}_{2}, \mathrm{C}_{6} \mathrm{H}_{2}, \mathrm{C}_{8} \mathrm{H}_{2}, \mathrm{C}_{10} \mathrm{H}_{2}$ のようなポリアセチ レンが最も重要な役割を果たしていることを結論し た。彼らによると，このポリアセチレンはラジカル濃 度の高い反応帯の初期につくられ，それから次第に増 加して反応帯の終り頃最大に達するがここで炭素生成 の核が完成され，その後は単に物理的に生長していわ ゆる luminous zoneが形成されるという。したがつて， この場合反応帯から下流にゆくにつれ炭素の粒子径は 増すが，その数は逆に減少することになる。第10図に はアセチレン一酸素火炎中のポリアセチレン濃度と位 置の関係を同じ炎に対する $\mathrm{CH}, \mathrm{C}_{2}, \mathrm{OH}$ などの発光 強度の変化とともに示した。なお，炭素粒子の大きさ

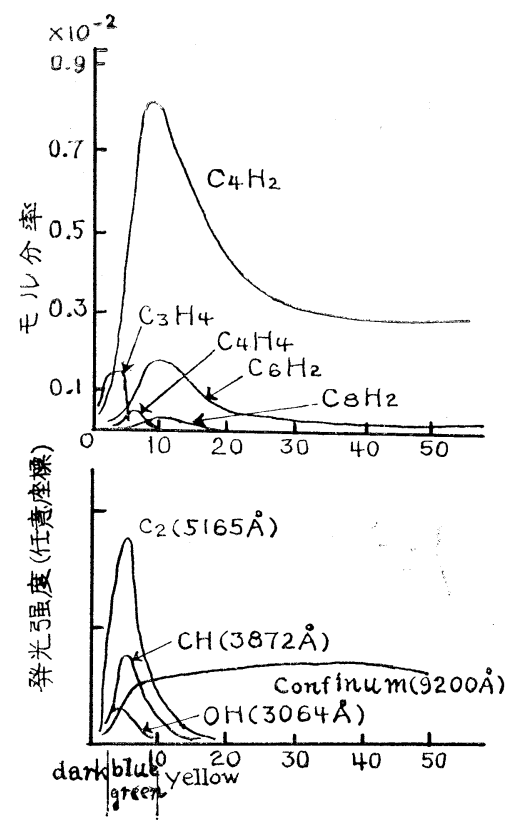

\section{第10図 アセチレン一酸素平面炎中のポ リアセチレンの分布 [Bonne, Homann, Wagner (1965)]}

については今まではほとんど電子顕微鏡を使用して求 めていたが，最近ふたたび炭素粒子による光の散乱を 利用する方法が注目され, Erickson, Williams, Ho-

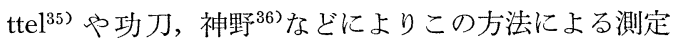
が試みられている。この方法は炎に直接触れることな く粒子径を求められる点で, 採取法に優るものである が, 光の散乱にはその中に含まれる大きな粒子が結果 に大きな影響を与えることが久点で, Hottel らがベン ゼン一空気混合炎に適用した結果では $250 \AA$ 位の炭素 に少なくとも数\%は $1,850 \AA$ という大きな粒子が含ま れていると仮定しないと，Mie 理論を用いた解析が実 験的な散乱光の角度分布の結果に一致しないといらこ とである。功刀らもほぼ同じよらな結果を得ているが， 彼らはこの方法で得られた粒径分布を゙もとにす寸の 生長は小さな粒子から次第に大きくなるのではなく, 逆にバーナーの出口から先にゆくにつれ小さくなると いう興味ある結論を得て，その成果を第11図の燃焼シ ンポジウムに問らている。さらに, Place と Weinberg ${ }^{37)}$ はメタン一空気の向流拡散炎に電界をかけ, それに よる炭素生成の速度や粒子径の変化を調べたが，この 結果によると一般に拡散炎に電界をかけると，その発 光強度は減少し，また粒子径は小さくなる。これは電 
界の存在する火炎中の pysolysis zone で生成した炭素 核は電荷起ちっ，ために電界で引かれ反芯带およびそ の後の領域に滞留する時間が減って生長しにくくな として説明されるが，この場合電荷の生ず石原因とし ては熱イオン化 (Thermionic) と他の化学種から生じ た電子の付着 (attachment) が考元られ，、ずれも炎 中で起こる。しかし, 彼らの測定によると, この原因 としては前者の方が可能性が大きく, それに基ずいて 炭素粒子は正の電荷をもつことが多いようである。第 11図には印加電圧によるす寸生成速度の変化の一例を 彼らの報文から引用した。ただし，図中 exhaustとあ

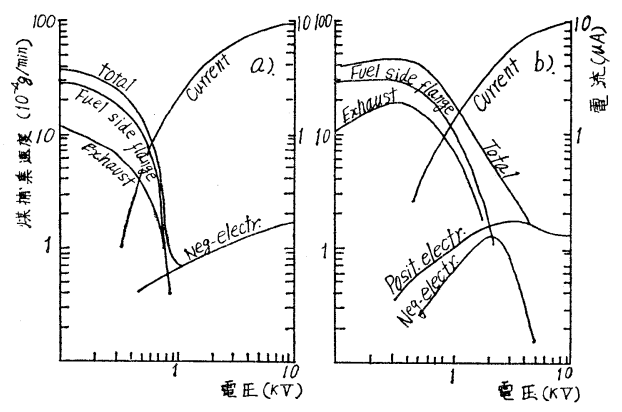

第11図 エチレン一空気火炎に電界を与 えた場合のすす捕集速度

a ) 燃料側の電極が正

b) 燃料の電極が負

[Place, Weinberg (1966)]

るのは燃燒生成ガス中から得られたす寸, electrode はバーナーロにつけた金網状電極に付着したもの, flange とあるのは向流拡散炎を安定化するためにバー ナー口のすぐ上に設けられたフランジに付着したす寸 を意味する。なお，この実験における粒子径は 100〜 $1,000 \AA$ であつたといら。この種の研究は今後いくつ か現われるだろらと思われるが，これらの研究は火炎 構造を明らかにするのみならず，電界によるすす生成 の減少, カーボン・ブラックの製造に㧍ける粒子径の 制御，また炎の熱輻射の電界による制御などの工業的 な利用につながる点ですこぶる興味深い。

このほか, 都市ガス一空気混合気の燃焼生成ガス中 にメタンを吹きんこだときのすすの生成速度を測つた Narasimhan と Foster ${ }^{38)}$ の研究や層流拡散炎の炭素 生成に対する空気流量や添加物の影響を調べた Ray と Long ${ }^{39)}$ の研究，また都市ガス一空気火炎中に芳香 族炭化水素を添加したときの寸寸の生成を取扱つた Scully と Davis ${ }^{40)}$ の論文などもあるが，火炎構造の研
究からすると，最初のものは Tesner ${ }^{411}$ のそれと似て

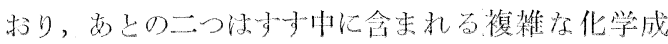
分，上くに多環化合物や添加物質のちがいに上る宸素

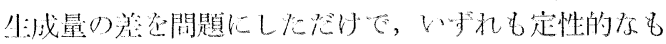
のである。

以上, 要するに火炎構造に関する最近の研究は, 化 学種にしてもイオンや炭素粒子の問題にしても，一㭙 前よりは著るしく進歩したことは確かであるがな お，現象の全貌が明らかになつたといら段階にはほぼ 遠く, 問題によつては測定が精密になつたためいよい よ複雑になり，かえつて見通しが悪くなつてきた傾向 もあるのではないかといら気がする。今後, 総合的な 研究の進歩が期待される所である。

\section{文献}

1) T. P. Pandya, F. J. Weinberg, 9th Symp. on Comb., p. 587 (1963)

2) T. P. Pandya, F. J. Weinberg, Proc. Roy. Soc., 279, 544 (1964)

3) M. M. Ibiricu, A. G. Gaydon, Comb. Flame, 8, 51 (1964)

4) M. Tuji, I. Yamaoka, 11th Symp. on Comb., (1966)，第 3 回燃焼シンポジウム（昭40）

5) J. A. Milne, F. T. Greene, J. Chem. Phys., 44, 2444 (1966), 10th Symp. on Comb., p. 153 (1965)

6) A. A. Westenberg, R. M. Fristrom, 10th Symp. on Comb., p. 473 (1965)

7) C. C. Feriso, C. B. Ludwig, F. P. Boynton, 10th Symp. on Comb., p. 161 (1965)

8) G. J. Penzias, 10th Symp. on Comb., p. 189 (1965)

9) E. C. Hinck, T. F. Seamans, M. Vanpee, H. G. Wolfhard, 10th Symp. on Comb., p. 21 (1965)

10) C. P. Fenimore, G. W. Jones, 10th Symp. on Comb., p. 489 (1965)

11) W. E. Wilson, Jr., 10th Symp. on Comb., p. 47 (1965)

12) W. G. Agnew, J. T. Agnew, 10th Symp. on Comb., p. 123 (1965)

13) J. N. Bradley, G. A. Jones, G. Skirrow, C. F. H. Tipper, 10th Symp. on Comb., p. 139 (1965)

14) B. H. Bonner, C. F. H. Tipper, Comb. Flame, 9, 317 (1965) 
15) S. Sueyasu, T. Hikita, Comb. Flame, 9, 1 (1965)

16) A. Levy, F. L. Merryman, Comb. Flame, 9. 229 (1965)

17) M. Vanpee, E. C. Hinck, T. F. Seamans, Comb. Flame, 9, 393 (1965)

18) J. A. Green, T. M. Sugden, 9th Symp. on Comb., p. 607 (1963), T. M. Sugden, 10th Symp. on Comb., p. 539 (1965)

19) H. F. Calcote, S. C. Kurzius, W. J. Miller, 10th Symp. on Comb., p. 605 (1965)

20) A. Fontijn, W. J. Mille, J. M. Hogan, 10th Symp. on Comb., p. 545 (1965)

21) A. Feugier, A. Van Tiggelen, 10th Symp. on Comb., p. 621 (1965)

22) P. F. Knewstubb, 10th Symp. on Comb., p. 623 (1965)

23) G. Wortberg, 10th Symp. on Comb., p. 651 (1965)

24) J. L. Franklin, M. S. B. Manson, 10th Symp. on Comb., p. 561 (1965)

25) S. L. Soo, R. C. Dimick, 10th Symp. on Comb., p. 699 (1965)

26) M. A. Biondi, T. R. Connor, C. S. Weller, W. H. Kasner, 10th Symp. on Comb., p. 579 (1965)

27) K. Schofield, T. M. Sugden, 10th Symp. on Comb., p. 589 (1965)

28) A. J. Borgers, 10th Symp. on Comb., p. 627 (1965)

29) B. E. L. Travers, H. Williams, 10th Symp. on Comb., p. 657 (1965)

30) D. L. Turcotte, W. Friedman, 10th Symp. on Comb., p. 673 (1965)

31) J. Lawton, F. J. Weinberg, Proc. Roy. Soc., 277, 468 (1964)

32) J. J. Macfarlane, F. H. Holderness, F. S. E. Whitcker, Comb. Flame, 8, 215 (1964)

33) U. Bonne, K. H. Homann, H. Gg. Wagner,

*低温に打ける酸化反応では, 低压爆発半島, 冷 炎, 多重発火など複雑な現象が現れ, そこで起る 化学反応もまた複雑で女り, 現在末だ, その中で 重要な役割を演ずるであろうと思われるラジカル 類を㨁接測定することはほとんど成功していな い。したがって, 統一的な結論が下せない状態で あるのでここでは制愛する ${ }^{1) ~ 3) 。 ~}$ 10th Symp. on Comb., p. 503 (1965)

34) K. H. Homann, M. Mochizuki, Wagner, Zett. Phys. Chem., 37, 299 (1963)

35) W. D. Erickson, G.C. Williams, H.C. Hottel, Comb. Flame, 8, 127 (1964)

36) M. Kunugi, H. Zinno, 11th Symp. on Comb. (1966) 神野博, 燃焼研究所, No. 12, 1 (1966)

37) E. R. Place, F. J. Weinberg, Proc. Roy. Soc, 289, 192 (1966)

38) K. S. Narasimhan, P. J. Foster, 10th Symp. on Comb., p. 253 (1965)

39) S. K. Ray, R. Long, Comb. Flame, 8, 139 (1964)

40) D. B. Scully, R. A. Davis, Comb. Flame, 9, 185 (1965)

41) P. A. Tesner, 7th Symp. on Comb., p. 546 (1959)

\section{III 燃焼炎におりる化学反応}

燃焼は物理的, 化学的過程を含む複雑な現象である が，最近特にその化学变化を基礎的な素反応から理解 しようといら動きが強くなつてきたことは, 最近の国 際然焼シンポジウム中の報文の傾向からもらかがらこ とができる。これはこれまでの多くの現象論的なデー タ一の蓄積により，然焼現象の輪廊がはつきりしてき たこととともに, 高温反応研究法および分析技術（た とえば ESR あるいは TOF 質量分析計）の著しい進 歩によるものである。

ここでは炭化水素の然焼を化学反応の面から理解与 るためになされた現在までの研究の大要を説明する。 炭化水素の燃燒中の反応は, 低温すなわら発火が起る までの酸化反応と異なる*。これは低温では酸化反応 の速度が個々の炭化水素により著しく異なるが, 燃焼 速度はそれ程変わらないことによつても理解される。 したがつて炭化水素類の高温酸化反応はかなり統一的 な見解を下すことができる。

Friedman と Burke ${ }^{4)}$ のプロパンの燃焼，あるいは Fristrom $^{5)}$ のメタンの然焼の研究に示される様に炭化 水素の燃焼炎は二つの反応带に分けられる。第一の段 階では $\mathrm{CO}, \mathrm{H}_{2}, \mathrm{H}_{2} \mathrm{O}$ と多くのラジカルを生成する。 飽和炭化水素の酸素過剩炎では

$$
\begin{aligned}
& \mathrm{C}_{n} \mathrm{H}_{2 n+2}+\mathrm{OH} \rightarrow \mathrm{H}_{2} \mathrm{O}+\mathrm{C}_{n} \mathrm{H}_{2 n+1} \\
& \mathrm{C}_{n-1} \mathrm{H}_{2 n+1} \rightarrow \mathrm{C}_{n} \mathrm{H}_{2 n-2}+\mathrm{CH}_{3}
\end{aligned}
$$

となり,これらはさらにラジカルと反応して種々の中 
䦎生成物を経て主に $\mathrm{CO}$ と $\mathrm{H}_{2} \mathrm{O}$ となる。一方然料過 剩资では

$$
\mathrm{C}_{n} \mathrm{H}_{2 n+2}+\mathrm{H} \rightarrow \mathrm{H}_{2}+\mathrm{C}_{n} \mathrm{H}_{2 n+1}
$$

となり,それらが再結合して，より高次の炭化水素とな るので反応は非常に複雑である。これらの反応のうち 水素引抜反応についてはかなりよくわかつている 第二段階では生成した $\mathrm{CO}, \mathrm{H}_{2}, \mathrm{H}_{2} \mathrm{O}$ と高濃度のラ ジカルとの反応で $\mathrm{CO}_{2}$ の生成とラジカルの再結合が 主反店である。一般の宸化水素について淀性的に以 上のような大体の反応経路が考えられているが，個々 の素反応の定量的なことについてはまだほとんどわか つていない現状である。したがつてここではよく研究 されている簡単な燃料，すなわち水素，一酸化炭素， メタン，アセチレンについて述べることにする。この らら水素一酸素の反応は最もよく研究されており, 現 在反応機構の大要がわかつている唯一の反応であり， それらの素反応の多くは炭化水素の場合にも現われ る。一酸化炭素の酸化は上述のよらに水素の酸化とと もに炭化水素炎の第二段階における主要な反応であ る。アセチレンはある意味で水素の場合に似ている点 があり，またメタンは最も基礎的な炭化水素であるの で割合よく研究されている。

限られた紙数でこれらの反応について詳しく述べる ことはもとより不可能であるので記述の足りない部分 については最近の Fristrom ${ }^{6)}$, Fenimore Semenov ${ }^{2)}$ の著書を参照していただきたい。

\section{1. 水素-酸素の反応}

この反応については現在その大要が明瞭に理解され

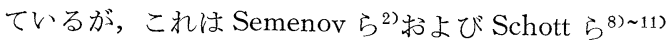
の研究に負うところが大きい。今後研究は非常に細分 化され，種々の関連現象にまでおよぶと思われる。

第 1 図に酸水素混合ガスを急激に衝撃波加熱した場 合の反応過程を示す。反応過程注順次，i）酸素, 水

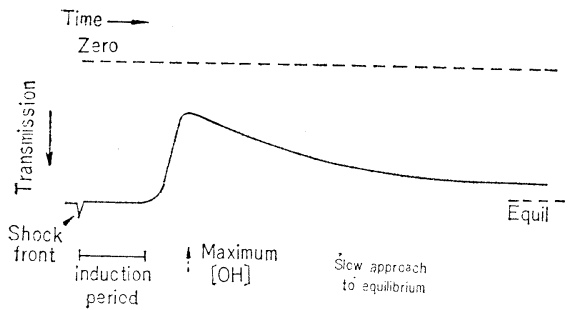

第1図 酸水素混合ガスを衝撃波加熱したと きの基底状態の $\mathbf{O H}$ の吸収のオシロ グラム（文献 (9)ょり) 素分子の振動緩和過程，ii） OH の濃度が小さくて测 企に加加らな，以扣る誘導期間，iii） $\mathrm{OH}$ 濃度增 加過程，iv）部分平衡，V）再結合過程，vi）平衡， 上考えられ\%。

1）振動緩和に関する理論 は古くから Landau, Teller $^{12)}$, Zener ${ }^{13)}$, Herzfeld ${ }^{14)}$ らに研究されている が近年実験技術の進歩とともに多くの分子について緩 和速度のデーターが蓄積され, 理論との比較が可能の 段階となつた ${ }^{15)}$ 。酸素 ${ }^{16)}$ 打よび水素分子 ${ }^{17)}$ につて子 すでに䒠測值が得られている。酸素分子の振動緩和が 酸水素反応の誘導期間におよぼす影響については $\mathrm{Be}-$ lles $ら^{18)}$ が計算から，筆者ら ${ }^{19)}$ が実験的に研究したが， 酸水素炎の条件ではその効果け現在の実験技術の誤差 範囲内であることが示された。ただ筆者らはもし水 素を重水素に招きかえるならば $2,000^{\circ} \mathrm{K}$ 以上では明 らかに效果を認め得ることを見出している。Bellesら の計算も大巾の近似法を用いており振動緩和と化学反 応の相関については理論的にもまた実験技術的にも今 後の問題である。

2）連鎖分岐反応

Semenov が提出した連鎖分岐反応の機構は ${ }^{2)}$ ，現在 でも大体受け入れられており，進歩は主に個々の素反 応についてのより広範囲かつ精確な值を得ることに向 けられている。起鎖反応

$$
\begin{aligned}
& \mathrm{H}_{2}+\mathrm{O}_{2} \rightarrow 2 \mathrm{OH} \\
& \mathrm{H}_{2}+\mathrm{M} \rightarrow 2 \mathrm{H}+\mathrm{M} \\
& \mathrm{O}_{2}+\mathrm{M} \rightarrow 2 \mathrm{O}+\mathrm{M}
\end{aligned}
$$

のうち(2), (3)の反応は 2 原子分子の解離であり,この 種の研究は最近非常 ${ }^{56) 311}$ に多く化学反応理論の面から も興味が持たれている。(1) の反応は正確に測定され 難い反応であるが, 最近 Gardiner らは誘導期間のデ 一ターを計算值と比較する方法を試みている ${ }^{20)}$ 。一方 Myerson の測定值 ${ }^{21)}$ もるが，両者の間にかなり大 きな差があり，問題はまだ解決されたとはいえない。 それにつづく三つの分岐反応

$$
\begin{aligned}
\mathrm{H}+\mathrm{O}_{2} & \rightarrow \mathrm{OH}+\mathrm{O} & & (4)^{8) 20) 22(23)} \\
\mathrm{O}+\mathrm{H}_{2} & \rightarrow \mathrm{OH}+\mathrm{H} & & (5)^{22) 24) 25)} \\
\mathrm{OH}+\mathrm{H}_{2} & \rightarrow \mathrm{H}_{2} \mathrm{O}+\mathrm{H} & & (6)^{22) 26)}
\end{aligned}
$$

については多くの研究があり信頼性のある速度定数が 得られつつある。現在これらを用いれば，少なくても 圧力の低、場合はラジカルの濃度の時間的変化を計算 し，種々の現象を説明することができる段階にいたつ ている。低温高压の場合は（4）の反応に競争する反応 として

$$
\mathrm{H}+\mathrm{O}_{2}+\mathrm{M} \rightarrow \mathrm{HO}_{2}+\mathrm{M}
$$


วรึいて

$$
\mathrm{HO}_{2}+\mathrm{H}_{2} \rightarrow \mathrm{H}_{2} \mathrm{O}_{2}+\mathrm{H}
$$

が重要らなる。(7)はつぎに述べる再絬全発热反応上し ても重要であり，速度定数が測定されている1127228)。 しかし(8)の反応については高圧の場合の発火遅れを 満足に説明できない29330)ことからまだ問題が残されて いる。

\section{3）部分平衡}

Schott らが見出した部分平衡の存在は ${ }^{9)}$, 高温化学 に特徵的なものとして注目される。ラジカルの蓄積す る (4) (5) (6) の反応は二分子反応であり, ラジカル の再結合は三分子反応であるので，高温では前者が後 者よりはるかに速く, 前者が実質上平衡に達した後に 後者が顕著になる。Schottらの行なつた部分平衡計算 は実測とよく一致している。

4) 再結合反忘

（4）（5）（6）の連鎖分岐反忘はラジカルを生成する 反応であり，熱的にはほとんど中性である。そしてそ れに続く再結合反忘により，平衡に近ずくと同時に熱 を発生する。現在

$$
\begin{aligned}
& 2 \mathrm{H}+\mathrm{M} \rightarrow \mathrm{H}_{2}+\mathrm{M} \\
& \mathrm{H}+\mathrm{OH}+\mathrm{M} \rightarrow \mathrm{H}_{2} \mathrm{O}+\mathrm{M} \\
& \mathrm{H}+\mathrm{O}_{2}+\mathrm{M} \rightarrow \mathrm{HO}_{2}+\mathrm{M}
\end{aligned}
$$

およびっら゙いて起る発熱反応としては

$$
\begin{aligned}
& \mathrm{H}_{2} \mathrm{O}+\mathrm{H} \rightarrow 2 \mathrm{OH} \\
& \mathrm{HO}_{2}+(\mathrm{H}, \mathrm{OH}, \mathrm{O}) \rightarrow \mathrm{O}_{2}+\left(\mathrm{H}_{2}, \mathrm{H}_{2} \mathrm{O}, \mathrm{OH}\right)
\end{aligned}
$$

が考えられている。これらはすべて大きな発熱反応で あり燃焼による発熱は主にこれらの反忘による。

Fenimore らは酸素過剩炎では (7)が最む重要であ り，水素過剩炎では (9) (10) (7) がともに重要である ことを示した ${ }^{28)}$ 。(9) の逆反応は水素の解離の反応で あり，これについては多くの研究が行われている ${ }^{31}$ 。 水素原子の直接再結合についても Larkin らが種々の third body について測定を行なつている55)。また(10) については最近 Schott らの研究がある。

\section{2. 一酸化炭素-酸素の反応}

$\mathrm{CO}$ の酸化は $\mathrm{H}_{2}$ の場合に比べて反応速度論的研究 ははるかに少ない。乾燥した $\mathrm{CO}-\mathrm{O}_{2}$ の反応は酸素 原子を Chain carrier とする分岐連鎖反応であること は認められているが，その機構はまだ確定していな い。Semenov ${ }^{1}{ }^{1}$ 分岐反応として

$$
\begin{aligned}
\mathrm{CO}+\mathrm{O} & \rightarrow \mathrm{CO}_{2}{ }^{*} \\
\mathrm{CO}_{2}{ }^{*}+\mathrm{O}_{2} & \rightarrow \mathrm{CO}_{2}+2 \mathrm{O}
\end{aligned}
$$

を考えた。これに対して Lewis らの $\mathrm{O}_{3}$ 生成説年2) も あるが, Gordon ら ${ }^{33)}$ Avramenko ら ${ }^{34)}$ の研究は上の
機構を支持するようである。

$\mathrm{CO}-\mathrm{O}_{2}$ 混合势入に微量でも $\mathrm{H}_{2} \mathrm{O}, \mathrm{H}_{2}$ が入った場

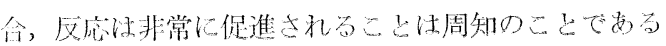
が35)，岑化水素炎の観点からはこの方が沈るかに重要 である。すなわち

$$
\begin{aligned}
& \mathrm{CO}+\mathrm{OH} \rightarrow \mathrm{CO}_{2}+\mathrm{H} \\
& \mathrm{H}+\mathrm{O}_{2} \rightarrow \mathrm{OH}+\mathrm{O}
\end{aligned}
$$

によつて反応が進行すると考えられている6)。また比 較的低温 $\left(\sim 500^{\circ} \mathrm{C}\right)$ では $\mathrm{HO}_{2}+\mathrm{CO} \rightarrow \mathrm{CO}_{2}+\mathrm{OH}$ も考 えられている ${ }^{54}$ 。(11)式の素反忘は多くの人々によつ て研究されている5 ${ }^{536)}$ 。

\section{3. アセチレン一酸素の反応}

前述の酸水素反応に招いて, 水素の濃度が大きいと きは (4) 式の反応がほぼ律速的となり, 広い温度範囲 にわたつて $\log \tau\left[\mathrm{O}_{2}\right], \tau$ は誘導期間, $1 / T$ がに対し ほぼ直線となる8 の酸化反応に対しても同様な事実を認め，水素の場合 との類推からつぎのような連鎖分岐機構を考えた。

$$
\begin{array}{ll}
\mathrm{C}_{2} \mathrm{H}_{2}+\mathrm{O}_{2} & \rightarrow \mathrm{H}, \mathrm{O}, \mathrm{OH}, \mathrm{C}_{2} \mathrm{H} \\
\mathrm{H}+\mathrm{O}_{2} & \rightarrow \mathrm{OH}+\mathrm{O} \\
\mathrm{O}+\mathrm{C}_{2} \mathrm{H}_{2} & \rightarrow \mathrm{C}_{2} \mathrm{H}+\mathrm{OH} \\
\mathrm{OH}+\mathrm{C}_{2} \mathrm{H}_{2} & \rightarrow \mathrm{C}_{2} \mathrm{H}+\mathrm{H}_{2} \mathrm{O} \\
\mathrm{C}_{2} \mathrm{H}+\mathrm{C}_{2} \mathrm{H}_{2} & \rightarrow \mathrm{C}_{4} \mathrm{H}_{2}+\mathrm{H}
\end{array}
$$

後に Kistiakowsky らは実験をやり直して ${ }^{39940)}$

$$
\begin{aligned}
& \mathrm{C}_{2} \mathrm{H}+\mathrm{O}_{2} \rightarrow 2 \mathrm{CO}+\mathrm{H} \\
& \mathrm{C}_{2} \mathrm{H}+\mathrm{O}_{2} \rightarrow \mathrm{CO}_{2}+\mathrm{CH} \\
& \mathrm{CH}+\mathrm{O}_{2} \rightarrow \mathrm{CO}+\mathrm{OH}
\end{aligned}
$$

の反応をつけ加えた。主分岐反応-(4) (16) のう ち (4) の反応が最も遅く律速的であるため $\mathrm{H}_{2}-\mathrm{O}_{2}$ の 場合とほぼ同様な挙動を示すと考えられた。第 2 図に 彼らの実験結果の一つを示す。また Gardiner らは $\mathrm{CH}^{*}$ の化学発光と $\mathrm{OH}$ の吸収を同時に測定して前者が消減 してから後者が現われることから

$$
\mathrm{CO}+\mathrm{OH} \rightleftarrows \mathrm{CO}_{2}+\mathrm{H}
$$

が重要なことを指摘している ${ }^{41}$ 。

その後, 上述の素反応のうち, とくに(13)の反応, すなわち酸素原子とアセチレンの反忘について常温で 研究が行なわれたが ${ }^{2243)}$ ，その場合この反応は(13)式 に示すような簡単なものではなく

$$
\mathrm{C}_{2} \mathrm{H}_{2}+\mathrm{O} \rightarrow \mathrm{CH}_{2}+\mathrm{CO}
$$

につゔく複雑なものであることが認められた。

アセチレンの酸化反応に扔いて特に興味あることは イオンの生成である。炭化水素炎では一般に Saha 式 で予言されるより，はるかに多くのイオンが存在する こと, すなわち化学イオン化が認められて㧍り, 現象 


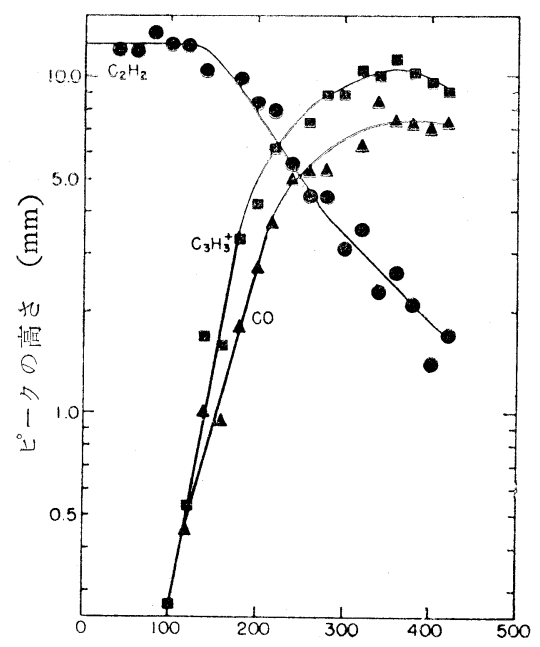

時間 ( $\mu \mathrm{Sec})$

第 2 図 アセチレン一酸素混合ガスを衝撃波 加熱したとき TOF 質量分析計で測 定した生成物の時間的変化。縦軸に はオシログラムに記録された質量ス ペクトルのピークの高さをとつてあ る(文献 (39) より)。

論的には Sugden, Calcote, Van Tiggelen らによつ て多くの研究がなされているが44), 速度論的にはアセ チレンについての Kistiakowsky らの研究38740)45) が特 筆される。彼らはアセチレンと酸素の反応におけるイ オン化は化学発光と密接な関係があることを認め

$$
\begin{array}{ll}
\mathrm{CH}\left(X^{2} \Pi\right)+\mathrm{O} & \rightarrow \mathrm{HCO}^{+}+e \\
\mathrm{CH}\left(A^{2} \Delta\right)+\mathrm{O} & \rightarrow \mathrm{HCO}^{+}+e \\
\mathrm{CH}\left(A^{2} \Delta\right)+\mathrm{C}_{2} \mathrm{H}_{2} & \rightarrow\left[\mathrm{HC}-\mathrm{HC}^{+}+e\right. \\
&
\end{array}
$$

の機構を提出している。またアセチレンと酸素原子の 反応によるイオン化については Fontjin ${ }^{46)}$, Arrington ${ }^{42)}$ らの研究がある。

\section{4. メタン-酸素の反応}

メタンの炎中の反応は定性的にはかなり明瞭になつ てきた ${ }^{6) 7}$ 。第 3 図からみられるよらにメタンの炎中の 反応はつぎの 4 つの過程にわけられる。
i ) メタン消失反応
ii）一酸化炭素生成反応
iii）炭酸ガス生成反応
iv) 再結合反応

i ）はメタンがメチル基になる反応で, 低温酸化機 構と異なりメタンとラジカルとの反忘による。酸素過

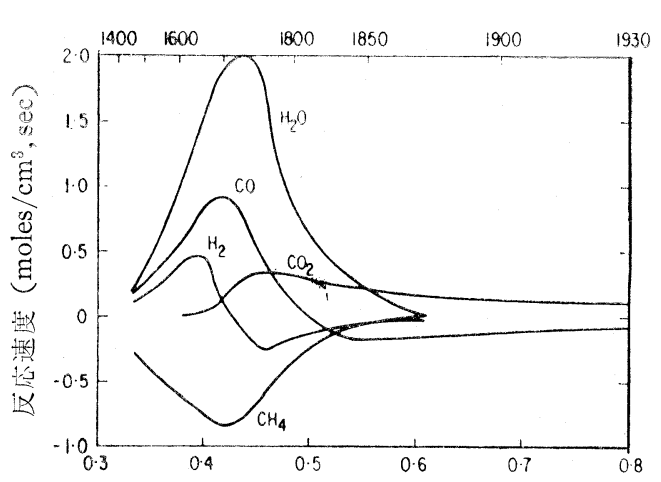

第 3 図 0.05 気圧の $\mathbf{C H}_{4}-\mathbf{O}_{2}$ 炎における $\mathrm{CH}_{4}$ の消滅速度と生成物の生成速 度（文献 (5)ょり)

剩炎では

$$
\mathrm{CH}_{4}+\mathrm{OH} \rightarrow \mathrm{CH}_{3}+\mathrm{H}_{2} \mathrm{O}
$$

が重要であり ${ }^{5)}$, メタン過剩炎では

$$
\mathrm{CH}_{4}+\mathrm{H} \rightarrow \mathrm{CH}_{3}+\mathrm{H}^{2}
$$

が重要である ${ }^{47) 。}$

ii）のCO生成反応は現在まだ明瞭に理解されてい ない。Semenov' ${ }^{2)}$ は

$$
\begin{aligned}
& \mathrm{CH}_{3}+\mathrm{O}_{2} \rightarrow \mathrm{H}_{2} \mathrm{CO}+\mathrm{OH} \\
& \mathrm{H}_{2} \mathrm{CO}+\mathrm{OH} \rightarrow \mathrm{HCO}+\mathrm{H}_{2} \mathrm{O} \\
& \mathrm{HCO}+\mathrm{OH} \rightarrow \mathrm{CO}+\mathrm{H}_{2} \mathrm{O}
\end{aligned}
$$

の機構を考えているが Fenimore と Jones は

$$
\mathrm{CH}_{3}+\mathrm{O} \cdots \cdots \rightarrow \mathrm{CO}
$$

の妥当性を主張しており ${ }^{48)}$ ，Fristrom はそれに対し てメタン過剩炎では

$$
\mathrm{CH}_{3}+\mathrm{O} \rightarrow \mathrm{H}+\mathrm{H}_{2} \mathrm{CO}
$$

を仮定している49)。しかし酸素過剩炎では(22)の反応 を捨てるべきでないとし, Norrish らの内光分解法に よる研究 ${ }^{50)}$ でも(22)の反応を支持している。Bundell らの最近の研究でも Semenov の機構により, 精密な 方法で取扱つている ${ }^{57)}$ 。

iii)iv)については，すでにそれぞれ一酸化炭素およ び水素の反応の項で述べてある。

以上のごとくメタン炎中の反志は，かなり理解され てきてるが, 発火にいたるまでの反応はもつと複雑で ある。筆者らは衝撃波管によりメタンの酸化反忘を研 究し, 酸素の濃度により発火の機構が異なることを見

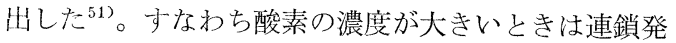
火であるが酸素の濃度が低くなると発火は熱的とな る。後者については Skinner も同じ見解をとつてい る52)。またSoloukhin らも同様な研究を行なつている が53), これらの研究では, 寸心゙て最初のメチル基生成 
反応は炎の場合と異なり

$$
\mathrm{CH}_{4}+\mathrm{O}_{2} \rightarrow \mathrm{CH}_{3}+\mathrm{HO}_{2}
$$

であるといら点では一致している。しかしより低濃 度, 高温かつ $\mathrm{Ar}$ で非常に希釈された Kistiskowsky らの研究 ${ }^{32}$ では初期反応が

$$
\mathrm{O}_{2}+\mathrm{Ar} \rightarrow 2 \mathrm{O}+\mathrm{Ar}
$$

として結果を説明している。

以上燃焼炎中に現れる化学反忘について 概説した が，全体の動向といらょり筆者の興味に重点をおき過 ぎた感がある。とくに発火にいたる低温酸化の反応は 膨大な資料がありながらほとんど割愛した。

現在化学工業においてもしばしば然焼反応が応用さ れているが，それらにここに述べたような考えは，あ まり利用されているように思えない。たとえば最近重 要になつてきた高圧下における炭化水素の酸化反応で も，実際に応用できる理論ないしはデータは見当ら ず，非常に不便を感ずることが多い。それらとの Gap を埋める中閒領域の研究が特に遅れていることを痛感 する。

\section{文献}

1) G. J. Minkoff, C. F. H. Tipper, "Chemistry of Combustion Reaction" Butterworths 1962

2) N. N. Semenov, "Some Problems of Chemical Kinetics and Reactivity" Pergamon 1958

3) V. Ya Stern "The Gas-Phase Oxidation of $\mathrm{Hy}$ drocarbons" Pergamon 1964

4) R. Friedman, E. Burke, J. Chem. Phys., 22, 824 (1954)

5) A. A. Westenberg, R. M. Fristron, J. Phys. Chem., 65, 591 (1961)

6) R. M. Fristrom, A. A. Westenberg, "Flame Structure" McGraw-Hill (1965)

7) C. P. Fenimore. "Chemistry in Premixed Flames" Pergamon (1964)

8) G. L. Schott, J. C. Kinsey, J. Chem. Phys., 29, 1177 (1958)

9) G. L. Schott, ibid., 32, 710 (1960)

10) G. L. Schott, P. F. Bird, ibid., 41, 2869 (1964)

11) R. W. Getzinger, G. L. Schott, ibid., 43, 3237 (1965)

12) A. Bethe, E. Teller, Aberdeen Proving Ground Report X-117

13) C. Zener, Phys. Rev., 37, 556 (1931), ibid., 38, 277 (1931)

14) R. N. Schwartz, Z. I, Slausky, K. F. Herzfeld,
J. Chem. Phys., 20, 1591 (1952) R. N. Schwartz, K. F. Herzfeld, ibid., 22, 767 (1954)

15) R. C. Millikan, D. R. White, ibid., 39, 3209 (1963). S. W. Benson, G. C. Berend, ibid., 44, 470 (1966)

16) D. R. White, R. C. Millikan, ibid., 39, 1803 (1963). D. R. White, R. C. Millikan, ibid., 39, 1807 (1963)

17) J. H. Kifer, R. W. Lutz, ibid., 44, 668 (1966)

18) F. E. Belles, M. R. Lauver, "10th Symp. on Combustion” p. 285, Combustion Institute, 1965

19) T. Asaba, W. C. Gardiner, R. F. Stubbman, ibid., p. 295.

20) D. L. Repley, W. C. Gardiner, J. Chem. Phys., 44, 2285 (1966)

21) A. L. Myerson, CAL Report, No. AD-1689A3 (1964)

22) F. Kaufman, F. P. Del Greco, "9th Symp. on Combustion" p. 659 Academic 1963

23) M. A. A. Clyne, B. A. Thrush, Proc. Roy. Soc., (London) A275 544 (1963)

24) C. P. Fenimore, G. W. Jones, J. Phys. Chem., 65, 993 (1961)

25) R. R. Baldwin, Trans. Faraday Soc., 52, 1344 (1956)

26) G. Dixon-Lewis, A. Williams "9th Symp, on Combustion" p. 576, Akademic, 1963

27) G. B. Skinner, G. H. Ringrose, J. Chem. Phys., 42, 2190 (1965)

28) C. P. Fenimone, G. W. Jones, 10th Symp. on Combustion" p. 489, Combastion Institute, 1965

29) V. V. Voevodsky, R. I. Soloukhin, ibid., 279.

30) H. Miyama, T. Takeyama, J. Chem. Phys., 41, 2287 (1964)

31) W. C. Gardiner, G. B. Kistiakowsky, ibid., 35, 1765 (1961). J. P. Rink, ibid., 36, 262 (1962). E. A. Sutton, ibid., 36, 2923 (1962). R. W. Patch, ibid., 36, 1919 (1962)

32) G. von Elbe, B. Lewis, W. Roth, " 5th Symp. on Combustion" p. 610 Reinhold, 1955

33) A. S. Gordon, R. H. Knipe, J. Phys. Chem., 59, 1160 (1955)

34) F. Kaufman, "Progress in Reaction Kinetics" p. 30, Pergamon 1961 
35) R. A. Wires, L. A. Watermeier, R. A. Strhlow, J. Phys. Chem., 63, 989 (1959)

36) C. P. Fenimore, G. W. Jones, J. Phys. Chem., 62, 1578 (1958)

37) W. C. Gardiner, J. Chem. Phys., 35, 2252 (1961)

G. B. Kistiakowsky, L. W. Richards, ibid., 36, 1707 (1962). J. N. Bradley, G. B. Kistiakowsky, ibid., 35, 264 (1961)

38) C. W. Hand, G. B. Kistiakowsky, ibid., 37, 1239 (1962)

39) G. P. Glass, G. B. Kistiakowsky, J. V. Michael, H. Niki, "10th Symp. on Combustion" p. 513 Combustion Institute, 1965

40) G. P. Glass, G. B. Kistiakowsky, J. V. Michael, H. Niki, J. Chem. Phys., 42, 608(1965)

41) R. F. Stubbeman, W. C. Gardiner, ibid., 40, 1771 (1964)

42) C. A. Arrington, W. Brennen, G. P. Glass, J. V. Michael, H. Niki, ibid., 43, 525 (1965). C. A. Arrington, W. Brennen, G. P. Glars, J. V. Michael, H. Niki, ibid., 1489 (1965)

43) J. O. Sullivan, P. Warneck, J. Phys, Chem., 69, 1749 (1965)
44) K. E. Shuler, J. B. Fenn 編, "Ionization in High-Temperature Gases" Academic Press, 1962

45) G. B. Kistiakowsky, J. V. Michael, J. Chem. Phys., 40, 1447 (1964)

46) A. Fontijin, G. L. Baughman, ibid., 38, 1784 (1963)

47) C. P. Fenimore, G. W. Jones, J. Phys. Chem., 65, 2220 (1961)

48) C. P. Fenimore, G. W. Jones, ibid., 65, 1532 (1961)

49) R. M. Fristrom, "9th Symp. on Combustion" p. 560, Academic Press, 1963

50) J.F. McKellar, R.G. W. Norrish, Proc. Roy. Soc. A263, 51 (1961)

51) T. Asaba, K. Yoneda, N. Kakihara, T. Hikita, "9th Symp. on Combustion" p.193, Academic Press, 1963. G. B. Skinner, Ruehrwein, J. Phys. Chem., 63, 1736. (1959)

53) 文献 (32) の後 Comments の項

54) R. R. Baldwin, D. Jackson, R. W. Walker, S. J. Webster, "10th Symp. on Combustion" p. 423 Combustion Institute, 1965

55) F. S. Larkin, B. A. Thrush, ibid., p. 397.

56) K. L. Ray, ibid., p. 523.

\title{
Fundamental Research on Combustion
}

\author{
by Hiroshi Tsuji \\ *Kazuo Akita \\ Tetsuo Asaba \\ (Tokyo University, *Fire Defense Research Inst.)
}

SYNOPSIS : - Among various kinds of periodicals concerned with conbustion such as "Combustion \& Flame" published quarterly by Butterworths, London and others, the volume of the contributed papers for the International Symposium on Combustion is the best one to learn the trends in the fundamental research on combustion. The basis of selection of the contributed papers for presentation is more or less affected by the special circumstances of the Symposium local sponsors, for instance, in the 10th Symposium (1964), sessions were provided for combustion chemistry, flame spectroscopy (to include mass spectrometry), chemical reaction kinetics, detonation, combustion and flow, solid propellant combustion, etc. In addition, the discussion were organized on the following 
three topics: elementary combustion reactions. electrical properties of flame and aerodynamics in combustion. In the 11th Symposium, the sessions on flame structure and ionized species in flame were added besides the above, and the discussions on chemical kinetics and energy transfer in high temperature gases as well as heterogeneous combustion are to be given.

The points of interest in individual section are shifting, and especially the recent symposia have been centered on the ions in flame, which has possessed one field.

In writing the trends of fundamental research on combustion, following three parts were allotted to Tsuji, Akita and Asaba under the direction of Prof, Hikita (Tokyo Univ.), e.g., I) gas chemistry in combustion (combustion and flow) by Tsuji, II) flame structure by Akita and III) chemical reaction in combustion by Asaba. Of the above symposia items, descriptions of detonation and solid propellant combustion are Cack, and few are described on ions in flame. Moreover, these three papers are mostly served to the gas combustion but liquid, solid together with heterogeneous combustions are very scarce, of which it is expected to pick up next time.

Studies on combustion have recently been made remarkable progress in many divergences. Especially each field is expanding toward more fundamental area, thus those who have been working in combustion research have found it somewhat difficult to clearly understand the feature of development of study.

On the other hand among varions actual problems there are still many fields to be left unsolved for which fundamental studies are kcenly required, Also the middle domain to connect fundamental research with practical problem seems not to have been studied.

As for the order of the chapters, contrary to the ordinary ones, this paper is made in the order of macro-to-micro fields. This is due to the authors' idea that such an order may be more understandable for the readers because the more micro the theme to be taken up is, the later its progress in the same time.

(Summarized by Asaba) 